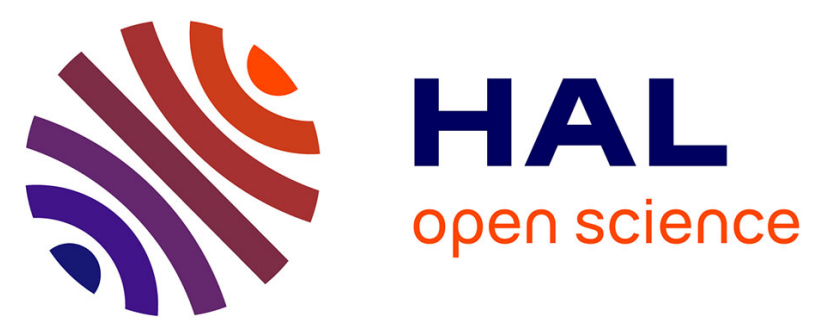

\title{
Ethynylglycine synthon, a useful precursor for the synthesis of biologically active compounds: an update. Part II: synthetic uses of ethynylglycine synthon
} Zohra Benfodda, David Bénimélis, Gianna Reginato, Patrick Meffre

\section{- To cite this version:}

Zohra Benfodda, David Bénimélis, Gianna Reginato, Patrick Meffre. Ethynylglycine synthon, a useful precursor for the synthesis of biologically active compounds: an update. Part II: synthetic uses of ethynylglycine synthon. Amino Acids, 2018, 50 (10), pp.1307-1328. 10.1007/s00726-018-2628-1 . hal-01859944

\author{
HAL Id: hal-01859944 \\ https://hal.science/hal-01859944
}

Submitted on 16 Jan 2019

HAL is a multi-disciplinary open access archive for the deposit and dissemination of scientific research documents, whether they are published or not. The documents may come from teaching and research institutions in France or abroad, or from public or private research centers.
L'archive ouverte pluridisciplinaire HAL, est destinée au dépôt et à la diffusion de documents scientifiques de niveau recherche, publiés ou non, émanant des établissements d'enseignement et de recherche français ou étrangers, des laboratoires publics ou privés.

\section{(ㅇ)(1) $\$$}

Distributed under a Creative Commons Attribution - NonCommercial - NoDerivatives 44.0 


\title{
Ethynylglycine synthon, a useful precursor for the synthesis of biologically active compounds: an update. Part II: synthetic uses of ethynylglycine synthon
}

\author{
Zohra Benfodda $^{1} \cdot$ David Benimélis ${ }^{1} \cdot$ Gianna Reginato $^{2} \cdot$ Patrick Meffre $^{1} \mathbb{C}$
}

\begin{abstract}
The ethynylglycine synthon \{(R)-2,2-dimethyl-3-(tert-butoxycarbonyl)-4-ethynyl-oxazolidine $\}$ is a chiral compound with valuable synthetic interest. An update (covering literature from 2005 to 2017) on the different synthetic utilities is reviewed and discussed.
\end{abstract}

Keywords Synthesis $\cdot$ Ethynylglycine synthon $\cdot$ Terminal alkyne $\cdot$ Metallation $\cdot$ Metal-catalyzed coupling $\cdot$ Cycloaddition

\begin{tabular}{|c|c|c|c|}
\hline \multicolumn{2}{|c|}{ Abbreviations } & LHMDS & Lithium bis(trimethylsilyl)amide \\
\hline Ac & Acetyl & MCPBA & $m$-Chloroperoxybenzoic acid \\
\hline \multirow[t]{2}{*}{ ACC synthase } & 1-Aminocyclopropane-1-carboxylate & $\mathrm{Me}$ & Methyl \\
\hline & synthase & Mts & 2,4,6-Trimethylbenzenesulfonyl \\
\hline All & Allyl & MW & Microwave \\
\hline $\mathrm{Bn}$ & Benzyl & NCS & $\mathrm{N}$-Chlorosuccinimide \\
\hline Boc & tert-Butoxycarbonyl & $o$ DPPBA & 2-(Diphenylphosphino)benzoic acid \\
\hline $\mathrm{Bu}$ or $n-\mathrm{Bu}$ & $n$-Butyl & $o$ DPPB & 2-(Diphenylphosphino)benzoate \\
\hline CAN & Cerium ammonium nitrate & $\mathrm{Ph}$ & Phenyl \\
\hline $\mathrm{Cbz}$ & Benzyloxycarbonyl & PLP & Pyridoxal phosphate \\
\hline dba & Dibenzylideneacetone & PTSA & $p$-Toluenesulfonic acid \\
\hline DCC & $N, N^{\prime}$-Dicyclohexylcarbodiimide & $\mathrm{RCM}$ & Ring-closing metathesis \\
\hline DIBAL-H & Diisobutylalumino hydride & SEM & 2-(Trimethylsilyl)ethoxymethyl \\
\hline DIPA & Diisopropylamine & TBAF & Tetrabutylammonium fluoride \\
\hline DIPEA & Diisopropylethylamine & TBAI & Tetrabutylammonium iodide \\
\hline DMAP & 4-Dimethylaminopyridine & TBDMS & tert-butyldimethylsilyl \\
\hline DMF & Dimethylformamide & TBDPS & tert-butyldiphenylsilyl \\
\hline DMP & Dess-Martin periodinane & $t$-Bu & tert-butyl \\
\hline ent-x & Enantiomer of compound $\mathbf{x}$ & TEMPO & 2,2,6,6-Tetramethylpiperidine 1-oxyl \\
\hline Et & Ethyl & TES & Triethylsilyl \\
\hline HMDS & Hexamethyldisilazane & Tf & Triflate \\
\hline \multirow[t]{2}{*}{ IDO } & Indoleamine 2,3-dioxygenase & TFA & Trifluoroacetic acid \\
\hline & & THF & Tetrahydrofuran \\
\hline \multicolumn{2}{|c|}{ Handling Editor: J. D. Wade. } & TMEDA & $N, N, N^{\prime}, N^{\prime}$-tetramethyl ethylenediamine \\
\hline \multicolumn{2}{|c|}{$\begin{array}{l}\triangle \text { Patrick Meffre } \\
\text { patrick.meffre@unimes.fr }\end{array}$} & Ts & 4-toluenesulfonyl \\
\hline \multicolumn{4}{|c|}{$\begin{array}{l}\text { UNIV. NIMES, EA7352 Chrome, Rue du Dr G. Salan, } \\
30021 \text { Nîmes Cedex 1, France }\end{array}$} \\
\hline \multicolumn{4}{|l|}{2} \\
\hline
\end{tabular}




\section{Introduction and goals}

In 2015, we decided to update the knowledge on ethynylglycine synthon 1a since our latest review in 2005 (Reginato et al. 2005b). The recently published part I of this review (Benfodda et al. 2015) dealt with the preparations of this compound (and its derivatives) from Garner's aldehyde 2a described in the literature so far (Fig. 1). The synthetic strategy adopted, the optical purity, and the preferred protection for the amino protecting group have been discussed there. The present part II of this review will be devoted to the uses of ethynylglycine synthon in synthesis that have been reported since our 2005 review (2005-2017), showing the broad range of recent synthetic applications of this polyfunctional chiral synthon.

The data that appeared after 2005 and that were not cited previously by us in our 2005 review (Reginato et al. 2005b) will be developed in this review; the previous references already cited in the 2005 review will only be cited in the paragraph headings, but the chemistry will not be developed. While writing this part II review, we noticed that a limited number of results earlier than 2005 were not developed in our 2005 review (Reginato et al. 2005b), that is why they now appear in the present review.

In neighbouring topics, it should be pointed out that Jirgensons recently published a review on the methods for the synthesis of $\alpha$-ethynylglycines derivatives described since 1996 (Bolsakova and Jirgensons 2016), the precedent review being our older report on $\beta, \gamma$-alkynyl $\alpha$-amino acids. (Meffre and Le Goffic 1996). We also published recently a comprehensive review on synthesis of $\alpha$-quaternary $\alpha$-ethynyl $\alpha$-amino acids (Boibessot et al. 2016b).

Due to the presence of the oxazolidine ring (used especially as a synthetic precursor of $\alpha$-amino acids) and of the terminal alkyne moiety, that allows several synthetic transformations, ethynylglycine synthon 1a is a useful building block for the synthesis of compounds of biological interest. The review will be organized considering the reaction type performed on the terminal alkyne (Fig. 1).

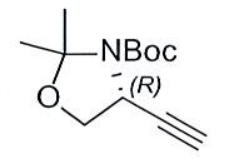

$1 \mathrm{a}$

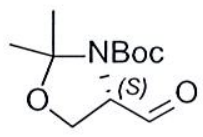

$2 a$
Fig. 1 (R)-2,2-dimethyl-3-(tert-butoxycarbonyl)-4-ethynyl-oxazolidine \{ethynylglycine synthon\} 1a and Garner's aldehyde 2a

\section{Metallation and reaction with electrophiles (Reginato et al. 1995, 1997; Meffre et al. 1996; Serrat et al. 1999; Cabarrocas et al. 2000a, b, 2001; Dondoni et al. 2001)}

\section{Electrophile is an aldehyde}

Historically, this reaction was the first to be reported in the field of ethynylglycine synthon chemistry, in 1990. Because the Corey-Fuchs strategy (Benfodda et al. 2015) from aldehyde ent-2a yields to ethynylglycine synthon lithium acetylide $\left(\mathbf{L i}^{+}\right)$-ent-1a, the latter was directly trapped with paraformaldehyde to give a propargyl alcohol derivative 3 (Chung and Wasicak 1990). This compound was further functionalized to lead to an oxotremorine analogue 4. Oxotremorine 5 is the active metabolite of tremorine, a muscarinic receptor agonist (Fig. 2).

Compound 3 was also used in 2010 to obtain the allenic oxazolidine 7 via a copper-mediated ortho(diphenylphosphanyl)benzoate (oDPPB)-directed $S_{N} 2^{\prime}$ reaction with an excellent regioselectivity $\left(S_{N} 2^{\prime} /\right.$ $\left.S_{N} 2=95 / 5\right)$ (Fig. 3) (Spangenberg et al. 2010).

The lithium acetylide derived from 1a was also reacted to TBDMS protected salicylaldehyde to give alcohol $\mathbf{8}$ (no yield given) which was then subjected to a one-pot acid-catalyzed nucleophilic substitution, fluoride TBDMS desilylation and exo-dig cycloisomerization to 2,3-disubstituted benzofuran 10 (Raji Reddy et al. 2012) (Fig. 4). It is worth noting that $\mathrm{B}\left(\mathrm{C}_{6} \mathrm{~F}_{5}\right)_{3}$ was used as acid catalyst instead of $\mathrm{BF}_{3} \cdot \mathrm{Et}_{2} \mathrm{O}$ because of the presence of acid labile acetonide group in $\mathbf{8}$.

The lithium acetylide derived from ent-1a was again used and converted to an alkynyl zinc reagent in the presence of excess zinc chloride, necessary to ensure a highly selective addition to aldehyde $\mathbf{1 1}$ in favor of the formation of the 1,2-syn alkoxide 12, followed by a ring opening of the epoxide activated by excess Lewis acid zinc chloride. $\alpha$ - $C$-(ethynylglycine)-galactoside $\mathbf{1 3}$ was thus obtained (Guillarme et al. 2006) (Fig. 5).

\section{Electrophile is a carboxylate or an isocyanate}

The lithium acetylide derived from ent-1a was also condensed with methylchloroformate (inverse addition method to avoid the formation of enyne due to deprotonation and acetone elimination) to obtain alkynoate ent-14. Hydrostannylation followed by Stille cross coupling with iodo tryptophan 16 and NBoc deprotection led to the synthesis of $\mathbf{1 7}$. Compound $\mathbf{1 7}$ is a precursor to (+)-asperazine, an alkaloid with cytotoxic activity against human leukemia (14 steps from ent-1a) (Govek and Overman 2007) (Fig. 6). 


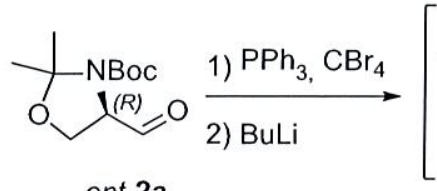

ent-2a<smiles>C#CC1COC(C)(C)[N+]1</smiles>

$\left(\mathrm{Li}^{+}\right)$-ent-1a

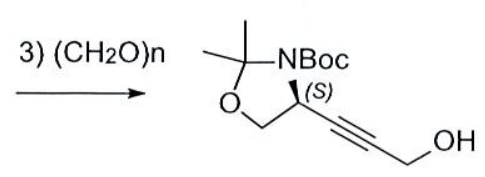

$3(22-36 \%$ from $2 a)$<smiles>NC1=N[C@H](C#CCN2CCCC2=O)CO1</smiles>

(32\% from 3$)$

Fig. 2 Synthesis of the oxotremorine analogue 4

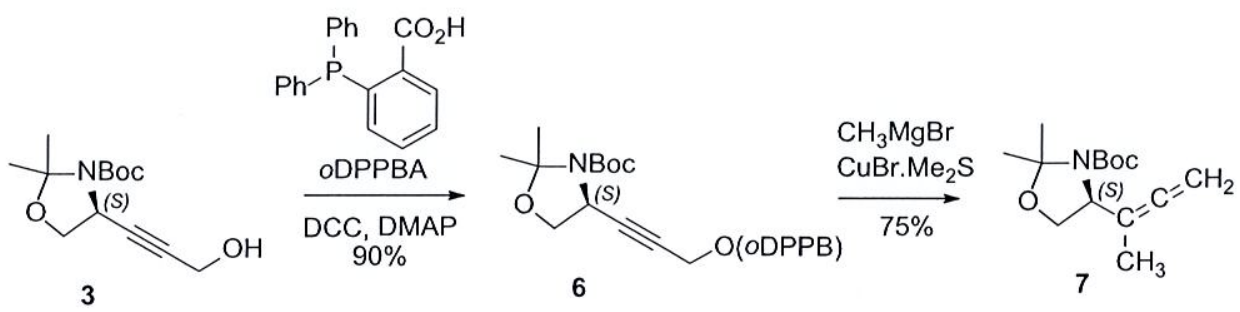

Fig. 3 Synthesis of the allenic oxazolidine 7 via $S_{N} 2^{\prime}$ reaction

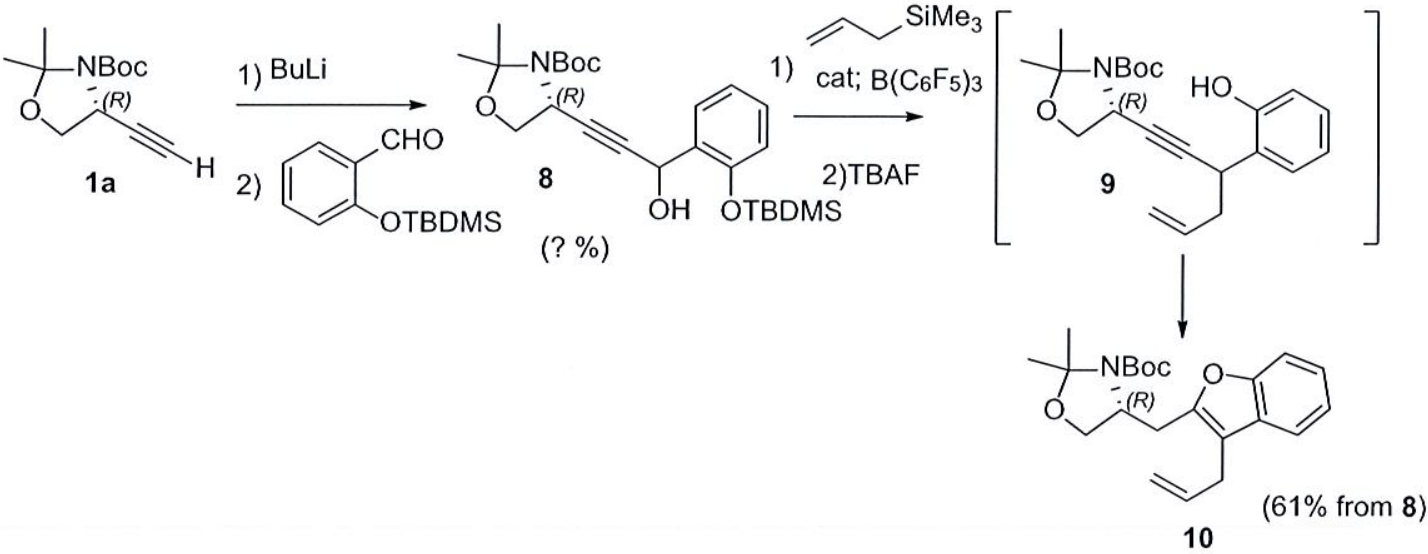

Fig. 4 Synthesis of the 2,3-disubstituted benzofuran $\mathbf{1 0}$

The alkynoate $\mathbf{1 4}$ (obtained by condensation of the lithium acetylide derived from 1a with methyl cyanoformate, Mander's reagent) was also engaged in a cycloaddition with benzyl formhydroximate $\mathbf{1 8}$ to afford isoxazole $\mathbf{1 9}$ which is a precursor of isoxazole $\mathbf{2 0}$ (9 steps from 1a). Isoxazole $\mathbf{2 0}$ is the precursor of a tetracycline core structure (11 steps from 20) (Wzorek et al. 2012) (Fig. 7).
The arylamide 22, also obtained by condensation of the lithium acetylide derived from $\mathbf{1 a}$ with isocyanate $\mathbf{2 1}$, was subjected to an In-mediated radical cyclization to yield oxindole $\mathbf{2 4}$, a possible precursor of TMC-95A, a naturally occurring proteasome inhibitor (Yanada et al. 2005) (Fig. 8). Indeed, looking at the configuration of the starting material 1a used by the authors, and at the configuration of the 


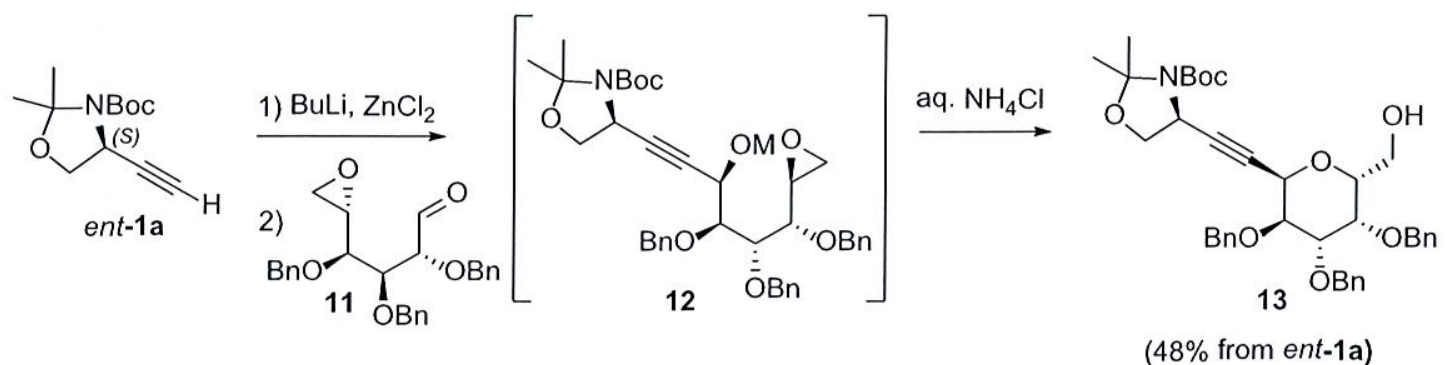

3) $\mathrm{LiBr}$

(48\% from ent-1a)

Fig. 5 Synthesis of the $\alpha$-C-(ethynylglycine)-galactoside $\mathbf{1 3}$

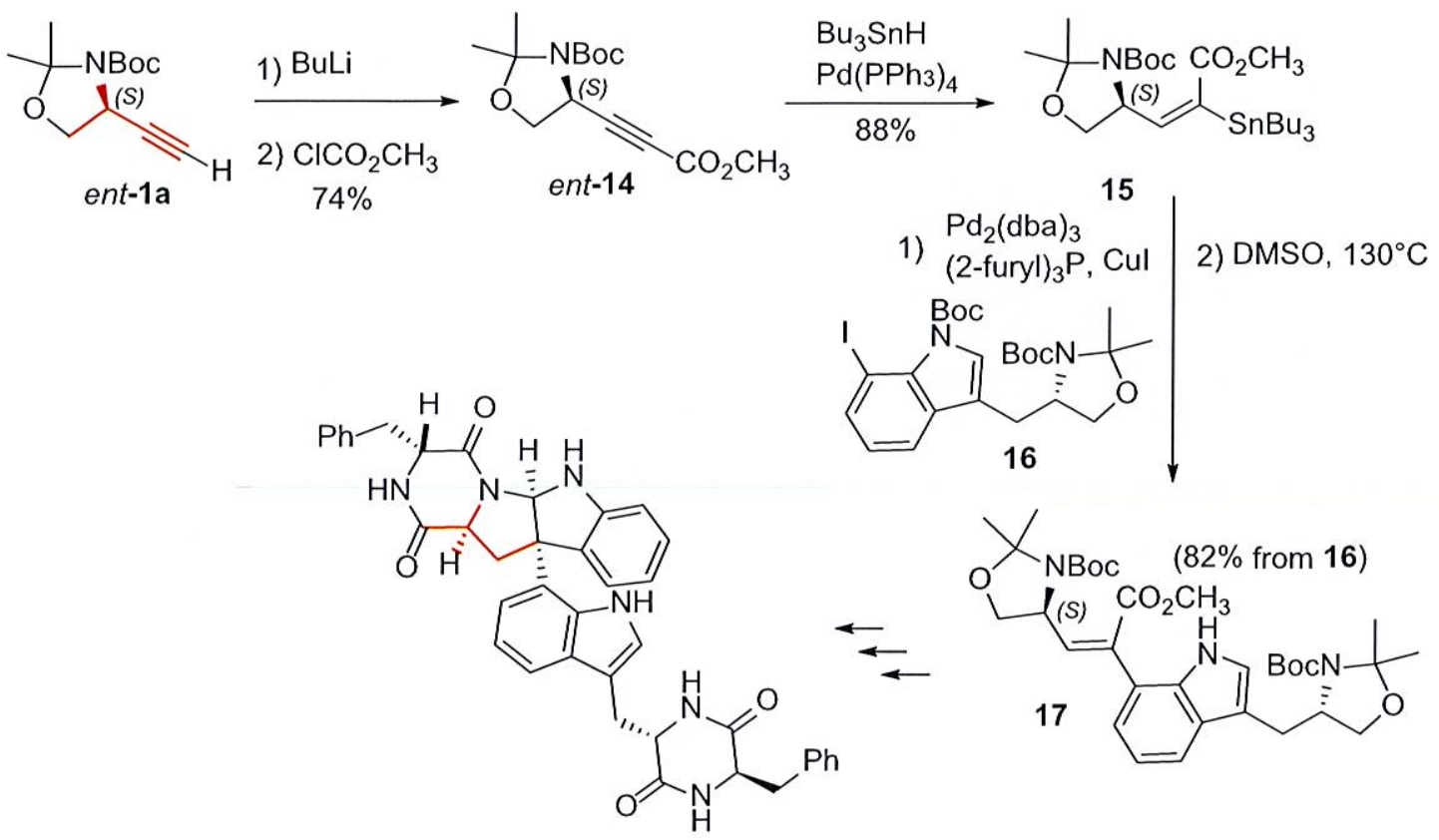

(+)-asperazine

Fig. 6 Synthesis of methyl enoate 17, precursor of (+)-asperazine

stereogenic carbon 8 in TMC-95A, it seems that using $(R)$ 1a oxindole $(R)-\mathbf{2 4}$ would be actually obtained, which is a precursor of a diastereoisomer of TMC-95A (Fig. 8).

\section{Electrophile is an alkyl halide}

Some time ago, our groups reported the synthesis of silylated amino acids using the ethynylglycine synthon (Meffre et al. 1996; Reginato et al. 1998, 1999). More recently, we described the synthesis of unsaturated amino acids containing an allyl silane moiety (Reginato et al. 2006), using a silylated alkyl halide as electrophile, the amino acid being obtained from the oxazolidine ring by oxidation (Fig. 9).
Finally, ethynylglycine synthon rac-1a was converted to cyclic carbamate 29. The terminus of the alkyne in $\mathbf{2 9}$ was functionalized with trimethyl silyl and phenyl groups to give $\mathbf{3 0}$ and $\mathbf{3 1}$ which were subjected to an allenic Alderene reaction to give unstable triene $\mathbf{3 4}$ and $\mathbf{3 5}$ (Brummond and Yan 2008) (Fig. 10). 


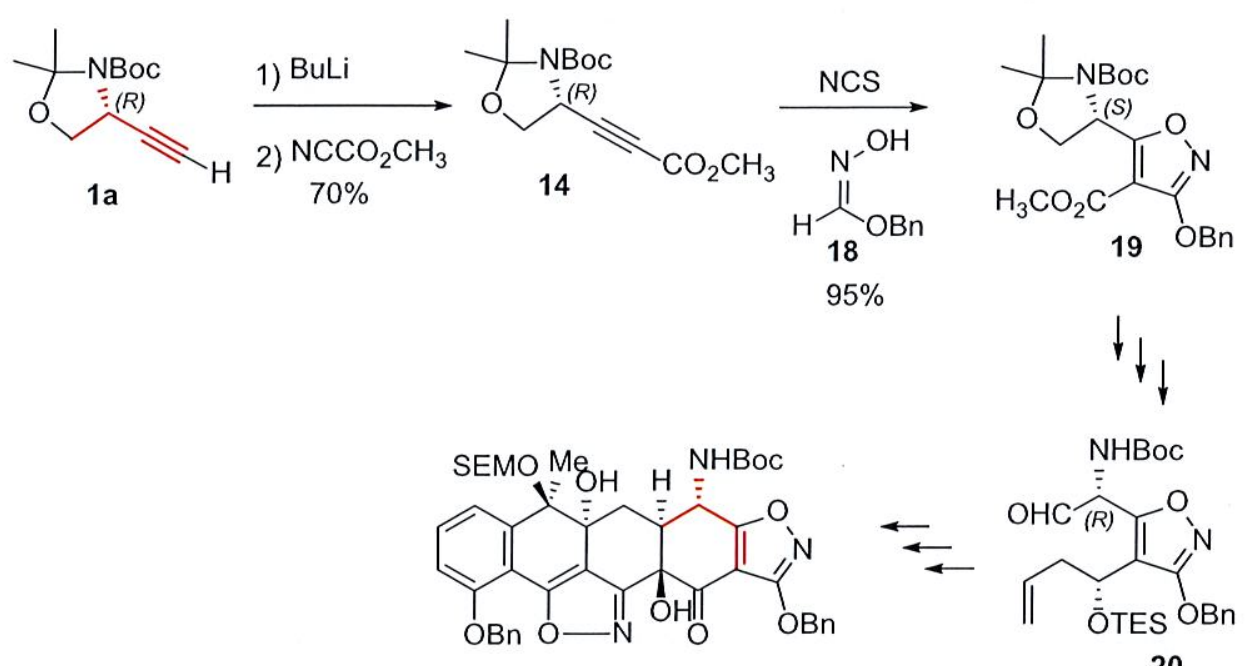

Tetracyclin core structure

Fig. 7 Synthesis of isoxazole $\mathbf{2 0}$, precursor of a tetracyclic core structure<smiles>C#C[C@H]1COC1(C)C</smiles>

$1 \mathrm{a}$<smiles>CC(C)(C)OCC(C#CC(=O)Nc1ccccc1I)[N+](=O)[O-]</smiles>

$79 \%$

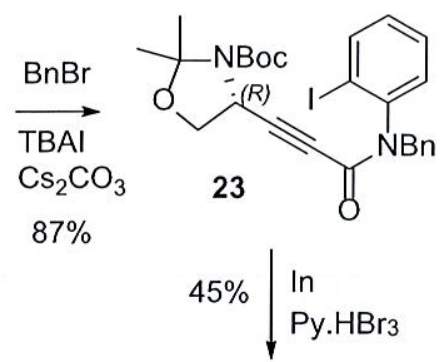

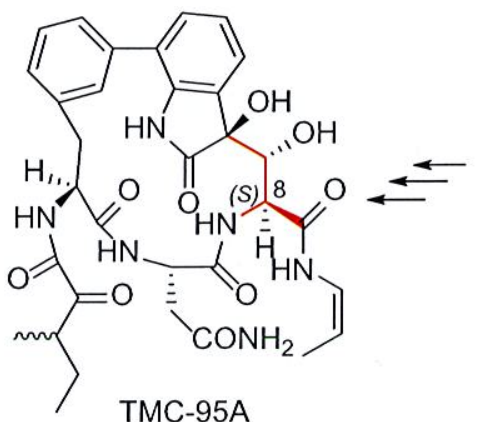

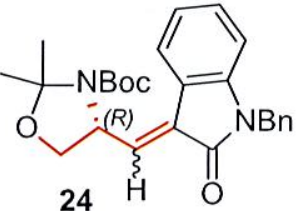

$(Z) /(E)=1.25$

Fig. 8 Synthesis of oxindole 24, precursor of TMC-95A

Pd-catalyzed coupling reactions: Sonogashira couplings (Reginato et al. 1997; Crisp et al. 1997; Cameron and Khambay 1998)

The terminal alkyne moiety on ethynylglycine synthon 1a allows functionalization using the well-known Pdcatalyzed Sonogashira coupling reaction (Chinchilla and Nájera 2007).
Furanomycin 41 is an unusual amino acid containing a 2,5-dihydrofuran ring that presents antibiotic activity (Katagiri et al. 1967; von Nussbaum et al. 2006) (Fig. 11).

The 2,5-dihydrofuran ring in the furanomycin analogue 40 was synthesized using a gold-catalyzed cycloisomerization of $\alpha$-hydroxyallene $\mathbf{3 8}$ as the key step to obtain the precursor bicyclic dihydrofuran 39 . $\alpha$-Hydroxyallene 38 is obtained from propargyl oxirane $\mathbf{3 7}$ by a copper-mediated $\mathrm{S}_{\mathrm{N}} 2^{2}$-substitution. Propargyl oxirane $\mathbf{3 7}$ is prepared from the corresponding enyne $\mathbf{3 6}$ which is obtained in turn from 


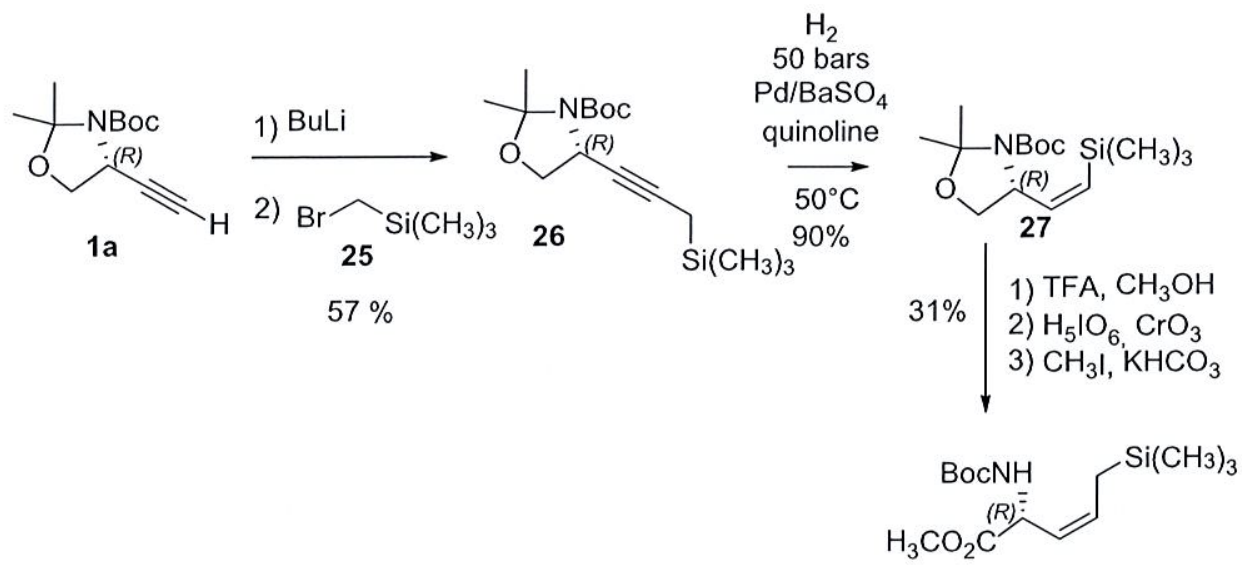

28

Fig. 9 Synthesis of an allylsilane amino acid derivative 28
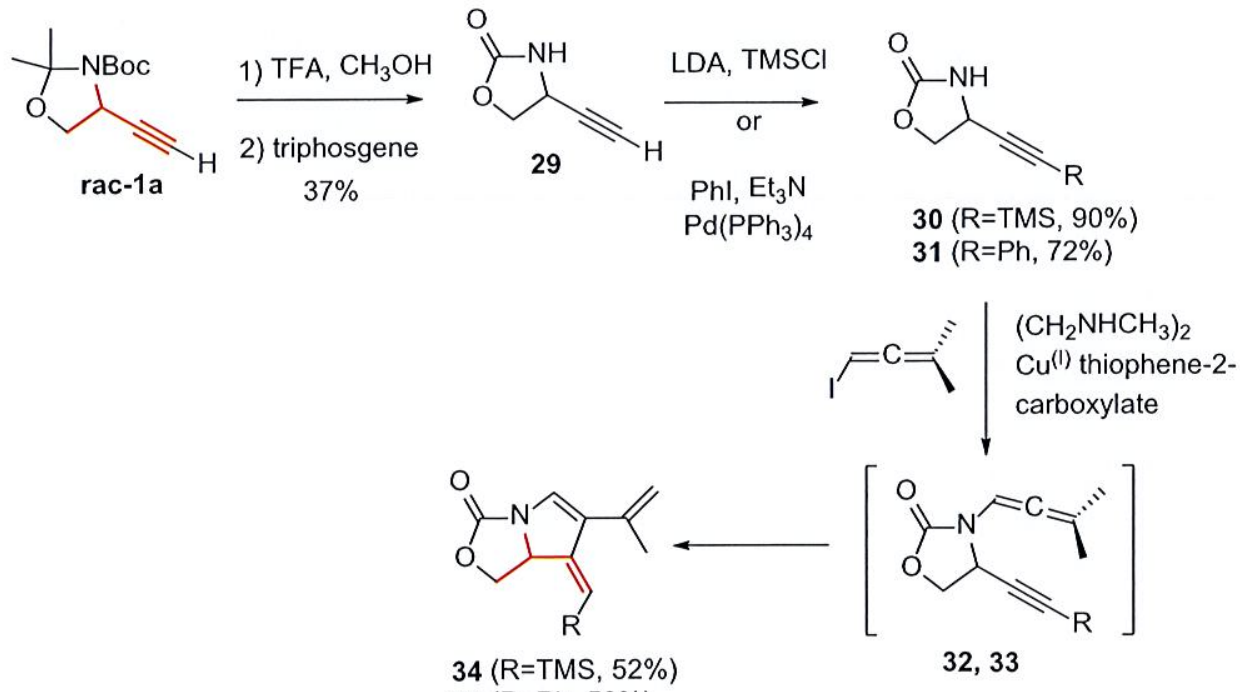

Fig. 10 Synthesis of conjugated trienes $\mathbf{3 4}$ and $\mathbf{3 5}$

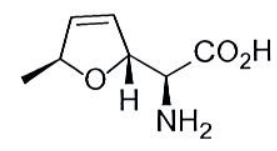

(+)-furanomycin 41

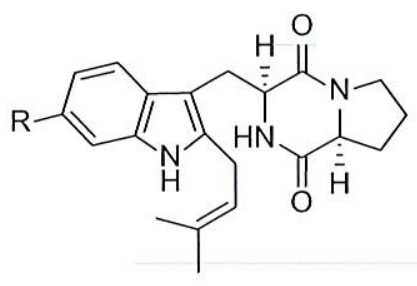

tryprostatin $\mathrm{A}\left(42, \mathrm{R}=\mathrm{OCH}_{3}\right)$ tryprostatin $B(43, \mathrm{R}=\mathrm{H})$

Fig. 11 Structures of (+)-furanomycin 41 and tryprostatins A 42 and B 43

ethynylglycine synthon 1a by a Sonogashira coupling with 1-bromocyclooctene (Fig. 12) (Erdsack and Krause 2007).

Tryprostatins A (42) and B (43) are naturally occurring 2,3-disubstituted indoles that present antimitotic properties (Fig. 11) (Evidente et al. 2014).

Total synthesis of tryprostatin B (Fig. 13) starts with Sonogashira coupling of the aromatic iodide $\mathbf{4 5}$ on the terminal alkyne of ent-1a. After partial reduction and dehydration, ortho-alkenyl isocyanide $\mathbf{4 7}$ is obtained. The 2,3-disubstituted indole 49 is obtained from 47 in a one-pot process by a radical cyclisation using V70 

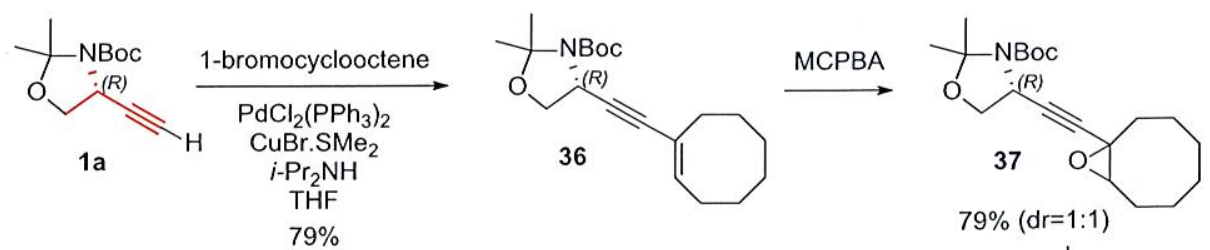

$79 \%(d r=1: 1)$

axd deprotection

$4035 \%$

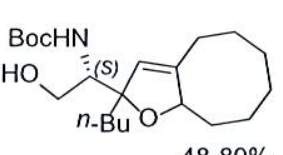

39

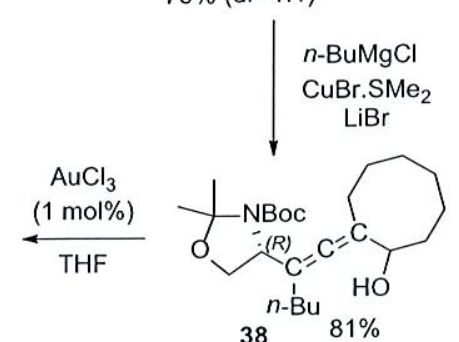

Fig. 12 Synthesis of furanomycin analogue $\mathbf{4 0}$

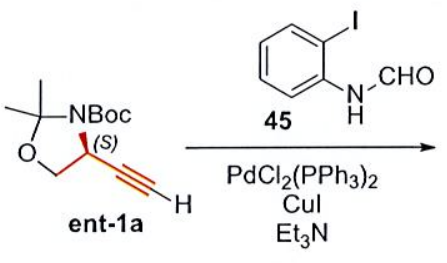

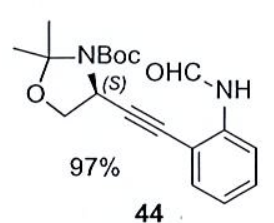

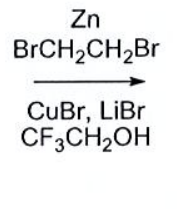<smiles>CC1(C)OCCC1C=Cc1ccccc1NC=O</smiles>

46<smiles>COC(C)(C)CC(C)(N)N=NC(C)(C#N)CC(C)(C)O</smiles><smiles>CC(C)=CCc1[nH]c2ccccc2c1CC1COC(C)(C)N1C(=O)OCc1ccccc1</smiles>

(82\% from 47 )

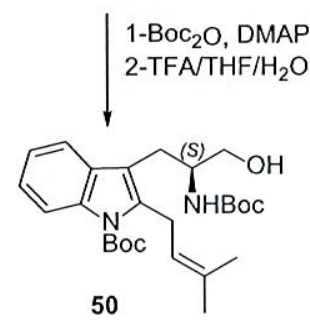

$87 \%$
TEMPO $\mathrm{Phl}(\mathrm{OAc}) 2$

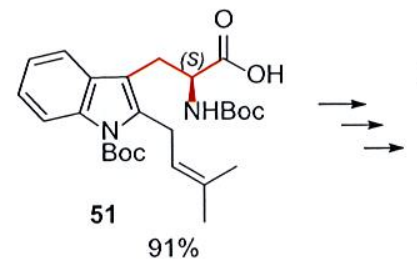<smiles></smiles>

tryprostatin B 43

Fig. 13 Synthesis of carboxylic acid 51, precursor of tryprostatine B 43

(2,2'-azobis(4-methoxy-2,4-dimethylvaleronitrile) as a radical initiator, followed by a Stille-type coupling reaction through the 2-stannyl indole intermediate 48. After protection/deprotection steps and oxidation, compound 51, key intermediate in the synthesis of tryprostatin B, is obtained.
(Yamakawa et al. 2010, 2011, 2014). Tryprostatin A is obtained using the same strategy.

Tryptophan analogues are interesting compounds, because they are possible indoleamine 2,3-dioxygenase (IDO) inhibitors and could have application in the 
treatment of inflammatory and neurodegenerative diseases (Röhrig et al. 2010). N,O-protected D-Homotryptophan $\mathbf{5 8}$ and its sulfur analogue $\mathbf{5 7}$ have been synthesized by Sonogashira coupling between 3 -iodoheteroarenes and ethynylglycine synthon 1a followed by reduction of the alkyne, oxidation of the alcohol, and esterification using diazomethane (Fig. 14) (Goswami et al. 2012b). The selenohomotryptophan 59 (Fig. 14) was synthesized by the same group using the same route (Goswami et al. 2013).
The same group described the synthesis of 2- and 3 -indolylglycine derivatives and of their oxygen analogues using ethynylglycine synthon 1a as starting material. Indolylglycines are interesting scaffolds which are present in bis-indole alkaloids like dragmacidins and hamacanthins (Goswami et al. 2012a).

3-Indolylglycine 68 and its oxygen analogue derivative 69 (Fig. 15) were prepared starting from the internal silyl derivatives 60 and 61 in turn obtained from 1a using the literature procedure (Meffre et al. 1996). The key step is a

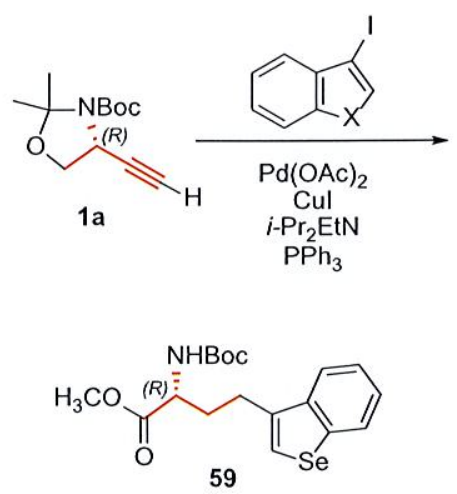<smiles>[X]c1ccccc1C#CC1C[NH2+]C(C)(C)OC1</smiles>

52 (X=NTs, 66\%) $53(\mathrm{X}=\mathrm{S}, 73 \%)$<smiles>[X]c1ccccc1CCC1=CC(=O)NC(C)(C)OC1</smiles>

54 (X=NTs, 84\%) $55(\mathrm{X}=\mathrm{S}, 80 \%)$

$$
\begin{aligned}
& \text { 1-PTSA, MeOH } \\
& \text { 2-Jones oxidation } \\
& \text { 3- } \mathrm{CH}_{2} \mathrm{~N}_{2}
\end{aligned}
$$<smiles>COC(=O)[C@H](CCc1c[nH]c2cc([C@H](C)C(=O)OCc3ccccc3)ccc12)C(=O)O</smiles>

(60\% ee)<smiles>[X]c1ccccc1CC[C@H](NC(=O)OC)C(=O)OC</smiles>

56 (X=NTs, $40 \%$ ) $57(X=S, 41 \%)$

Fig. 14 Synthesis of homotryptophane derivative $\mathbf{5 8}$

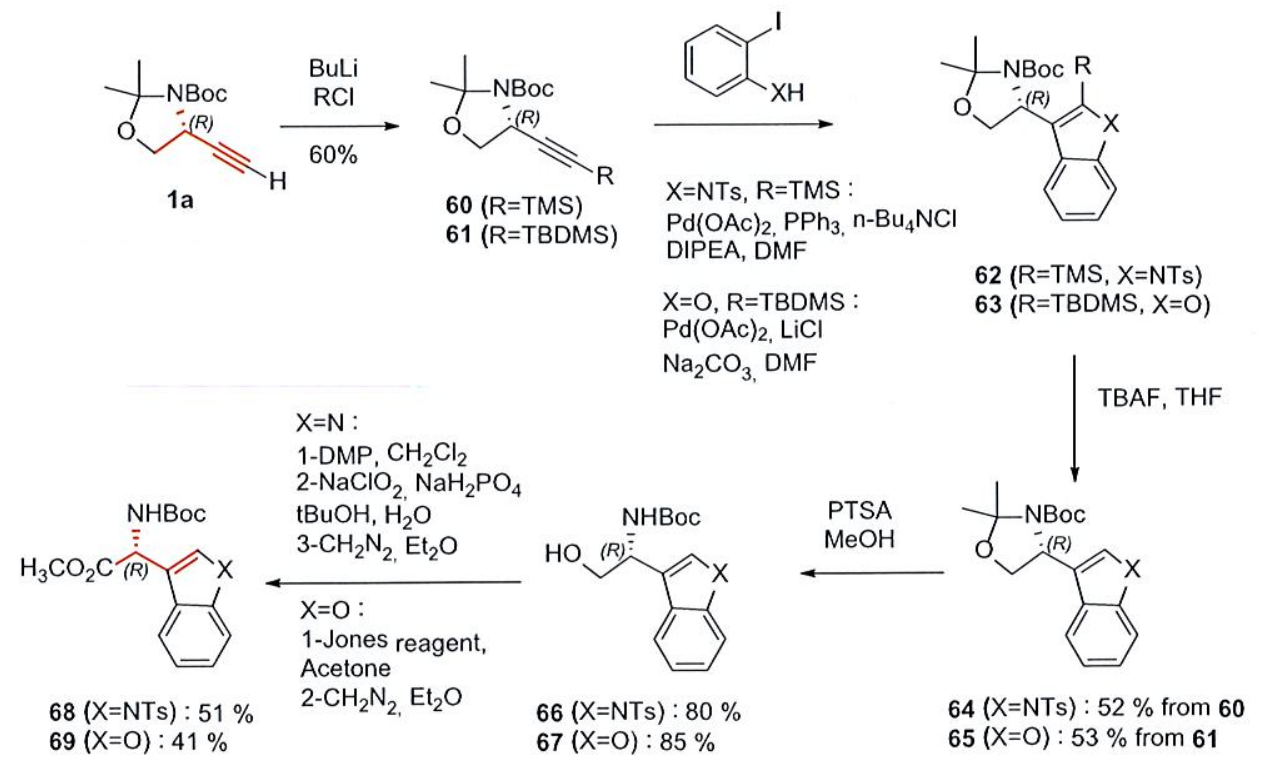

Fig. 15 Synthesis of 3-indolylglycine 68 and oxygen analogue 69 
Larock's heteroannulation with 2-iodoaniline and 2-iodophenol derivatives, to obtain compounds $\mathbf{6 2}$ and $\mathbf{6 3}$. After desilylation and acid-catalyzed oxazolidine opening into $\mathrm{N}$-Boc-protected amino alcohols 66 and $\mathbf{6 7}$, the N,O-protected 3-indolylglycine 68 and the oxygen analogue 69 are obtained by oxidation and esterification (Goswami et al. 2012a).

Unfortunately, the synthesis of the 2-substituted indole derivatives using the same strategy failed, due to the incompatibility of Boc-protecting group. For example Larock's iodocyclization conditions $\left(\mathrm{I}_{2}, \mathrm{CH}_{2} \mathrm{Cl}_{2}\right)$ proved to be problematic because of Boc-protecting group participation (nucleophilic attack). In this case, compound 71 was formed instead of expected indole derivative 72 (Fig. 16) (Goswami et al. 2012a).
To solve this problem, ethynylglycine synthon 1a was transformed into ethynyloxazolidinone $\mathbf{7 3}$, through the removal of acetonide protection and reaction of the resulting amino alcohol with thionyl chloride (Fig. 17). Coupling of cyclic carbamate $\mathbf{7 3}$ under Sonogashira conditions gave compounds $\mathbf{7 4}$ and 75, which after Boc protection and carbamate opening gave $\mathrm{N}$-Boc-protected amino alcohols 76 and 77, from which the N,O-protected 2-indolylglycine $\mathbf{7 8}$ and the oxygen analogue $\mathbf{7 9}$ are obtained by oxidation and esterification (Goswami et al. 2012a).

During the synthesis of the chronic obstructive pulmonary disease (COPD) biomarker (+)-desmosine 86, a cross-linking amino acid of elastin, two of the four amino acid moieties present in the structure are introduced simultaneously using a Sonogashira cross-coupling

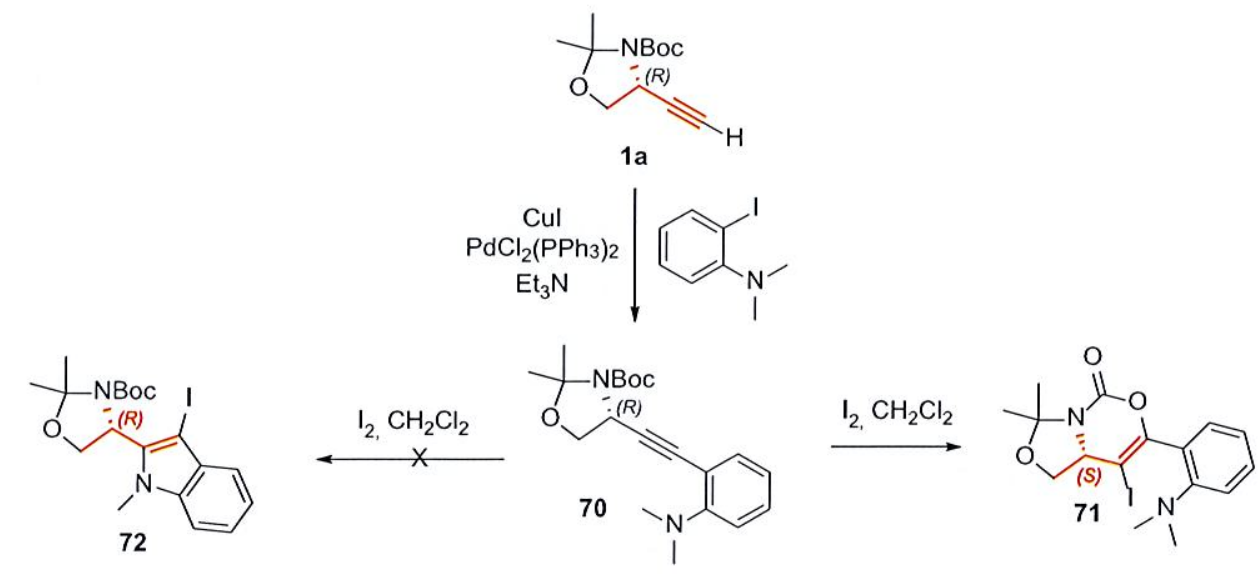

Fig. 16 Nucleophilic attack of Boc group under Larock's iodocyclisation condition: formation of cyclic carbamate 71 instead of indole 72<smiles></smiles>

1a

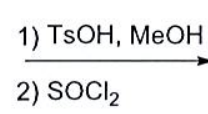

2) $\mathrm{SOCl}_{2}$

$$
\text { 73 }
$$

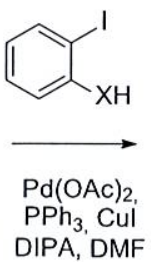<smiles>[X]c1ccccc1C1COC(=C)N1</smiles>

74 (X=NTs) : $70 \%$ $75(X=0): 44 \%$

$\mathrm{X}=\mathrm{NT}$ : :

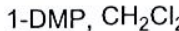
$2-\mathrm{NaClO}_{2} \mathrm{NaH}_{2} \mathrm{PO}_{4}$,

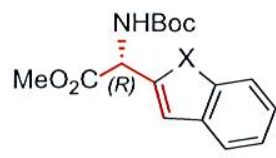
$\mathrm{t}-\mathrm{BuOH}, \mathrm{H}_{2} \mathrm{O}$ $3-\mathrm{CH}_{2} \mathrm{~N}_{2}$, ether

$\mathrm{X}=\mathrm{O}$ :

1-Jones reagents, acetone

78 (X=NTs) : $53 \%$ $79(X=0): 43 \%$

2- $\mathrm{CH}_{2} \mathrm{~N}_{2}$, ether
1) $\mathrm{Boc}_{2} \mathrm{O}, \mathrm{THF}, \mathrm{Et}_{3} \mathrm{~N}, \mathrm{DMAP}$ 2) $\mathrm{Cs}_{2} \mathrm{CO}_{3}, \mathrm{MeOH}$

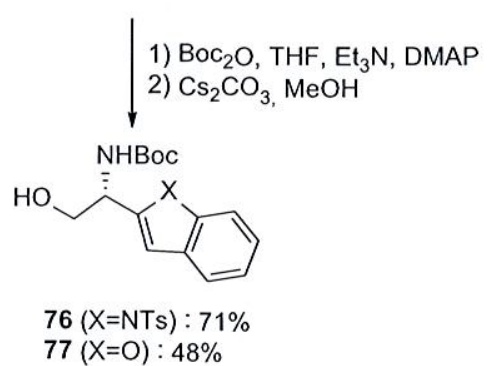

Fig. 17 Synthesis of 2-indolylglycine derivative 78 and oxygen analogue $\mathbf{7 9}$ 
reaction on ethynylglycine synthon ent-1a, as a first step. Another Sonogashira coupling reaction using propargylglycine derivatives $\mathbf{8 1}$ introduces a third amino acid moiety. Hydrogenation and usual functional group transformations led to the pyridine derivative $\mathbf{8 3}$, which is alkylated with the $\omega$-iodobutylglycine derivative $\mathbf{8 4}$ to give $\mathbf{N}$-Boc-protected desmosine $\mathbf{8 5}$. (+)-desmosine 86 is obtained after deprotection (Fig. 18) (Usuki et al. 2012; Yamada et al. 2015).

Compound $\mathbf{8 8}$ was prepared by Sonogashira coupling between the ethynylglycine synthon ent-1a and triflate 87 and used to prepare 8-hydroxy-3-substituted isocoumarine 89 using a gold(I)-catalyzed cyclization (Fig. 19) (Mallampudi et al. 2017).

\section{Cycloaddition reactions on the terminal alkyne (Falorni et al. 1998; Giacomelli et al. 2003)}

The copper(I)-mediated reaction between nitrones and terminal alkynes (Kinugasa reaction) is a well-known method used for the $\beta$-lactam ring formation (ComasBarceló and Harrity 2017). This reaction when applied to ethynylglycine synthon 1a leads to the formation of lactam 91 only in traces, although the same reaction conducted on D-glyceraldehyde alkyne analogue 92 led to lactam 93 in $46 \%$ yield and with a good diastereoselectivity (Fig. 20) (Stecko et al. 2009).

The $[3+2]$-cycloaddition of alkynes with in situ generated difluoromethyl nitrile oxide $\mathbf{9 4}$ (obtained from oxime 95) leads to $\mathrm{CF}_{2} \mathrm{H}$-isoxazoles. This reaction when applied

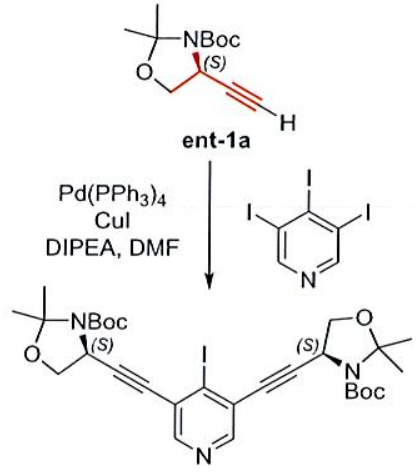

$80: 90 \%$

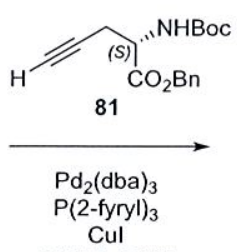

DIPEA, DMF

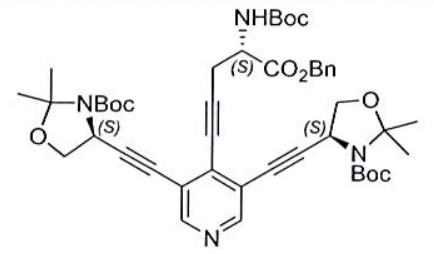

$82: 86 \%$

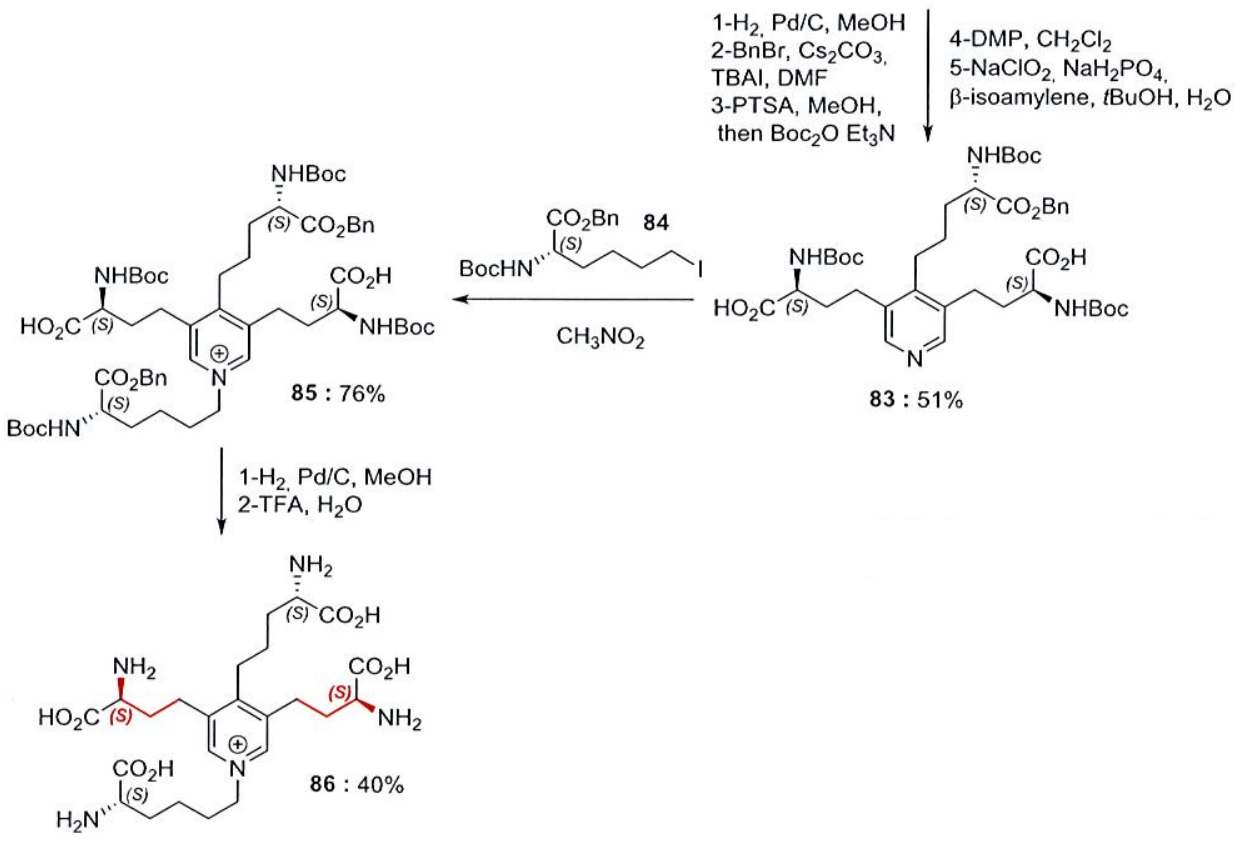

Fig. 18 Synthesis of (+)-desmosine 86 


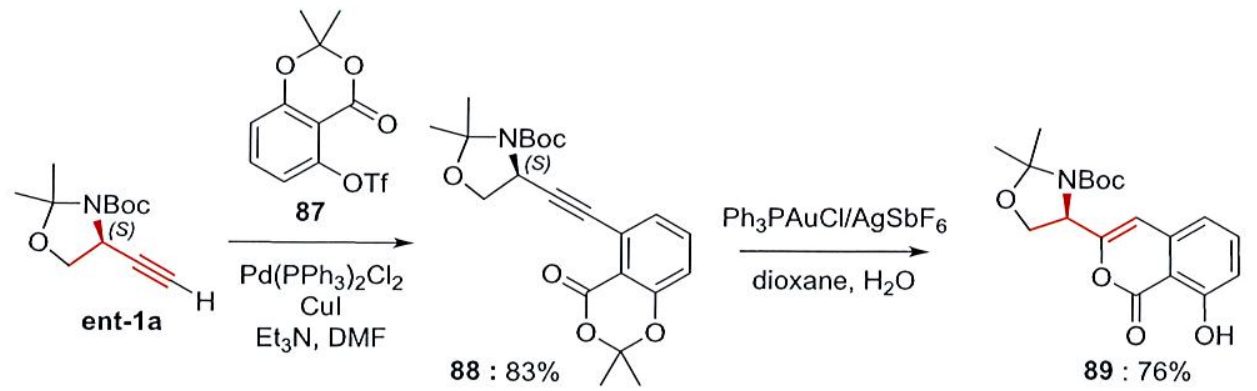

Fig. 19 Synthesis of isocoumarine derivative 89<smiles>C#CC1COC(C)(C)N1[O+]</smiles>

$1 a$<smiles>[O-][N+]1=CCCC1</smiles>

90

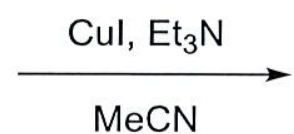

$\mathrm{MeCN}$<smiles>[R6]C1C(C2C(=O)N3CCCC23)COC1(C)C</smiles>

91 : traces<smiles>C#C[C@H]1COC(C)(C)O1</smiles>

92<smiles>[O-][N+]1=CCCC1</smiles>

90

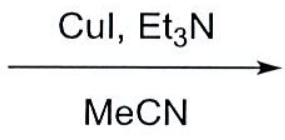

$\mathrm{MeCN}$<smiles>CC1(C)OC[C@H]([C@H]2C(=O)N3CCC[C@@H]23)O1</smiles>

d.r. $90: 10$

93 : $46 \%$

Fig. 20 Synthesis of $\beta$-lactams 91 and $\mathbf{9 3}$

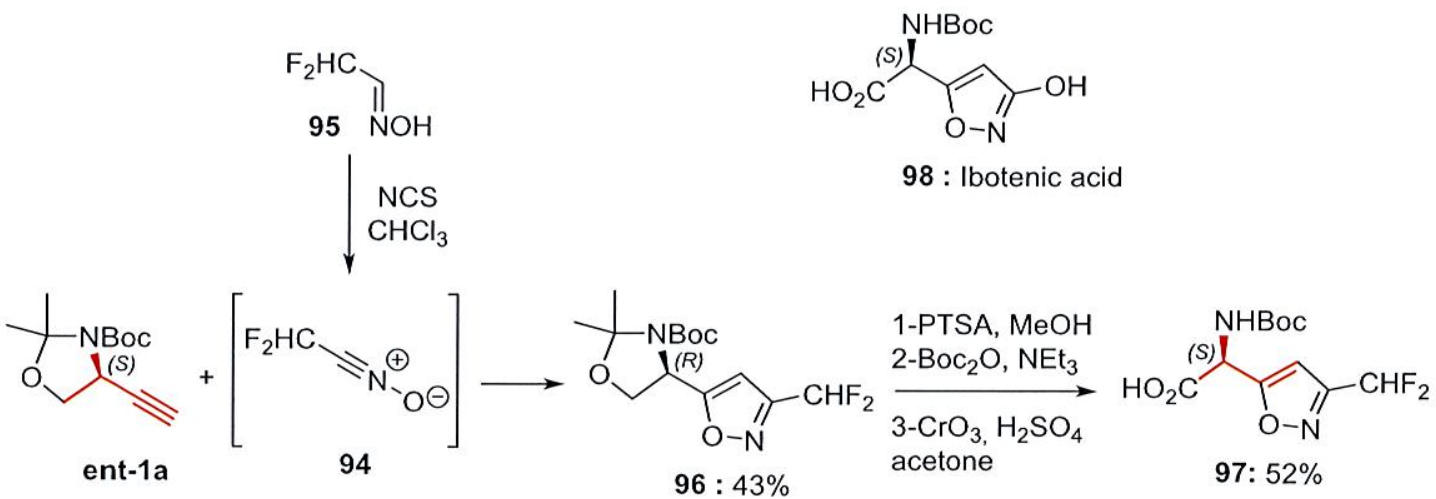

Fig. 21 Synthesis of isoxazole amino acid derivative 97

to ethynylglycine synthon ent-1a lets to isoxazole 96 , a precursor of the fluorinated isoxazole amino acid 97 (Fig. 21) (Khutorianskyi et al. 2017). Due to bioisosterism of $\mathrm{CHF}_{2}$ and $\mathrm{OH}$ groups, compound $\mathbf{9 7}$ is an analogue of ibotenic acid 98, a naturally occurring non-selective glutamate receptor agonist. (Frydenvang et al. 2010). 
For another similar reaction, see (Falorni et al. 1998; Giacomelli et al. 2003), already cited in our previous review (Reginato et al. 2005b).

Huisgen 1,3-dipolar cycloaddition of an alkyne and an azide is a well-known access to 1,2,3-triazoles (Huisgen 1963; Totobenazara and Burke 2015). $N$-styryl triazole 101 was obtained from ethynylglycine synthon ent-1a by Huisgen cycloaddition with azido styrene 99 (generated in situ from cinnamic acid 100, CAN and $\mathrm{NaN}_{3}$ ) (Kavitha et al. 2011) (Fig. 22).

Protected triazole amino acid $\mathbf{1 0 4}$ was also synthesized by us using the Huisgen cycloaddition of alkyne $\mathbf{1 0 2}$ and azido alanine $\mathbf{1 0 3}$ derived from L-serine. Protected aminoalcohol 102 was obtained by acid-catalyzed opening of the oxazolidine ring of ethynylglycine synthon ent-1a. Invertion of the deprotection/cycloaddition sequence led to lower yields (Boibessot et al. 2016a). Compound 104 is an analogue of rhizobitoxine 105, a plant growth regulator and inhibitor of PLP-dependent enzymes cystathionine $\beta$-lyase and ACC synthase (Fig. 22) (Owens et al. 1968; Xiong and Fuhrmann 1996; Yasuta et al. 1999; Sugawara et al. 2006).

Arylglycines are an interesting class of unusual amino acids, because this moiety is present in the structures of important biologically active natural products (Mazuela et al. 2017).

These types of compounds have been prepared by Dötz benzannulation between Fischer chromium carbene complexes $\mathbf{1 0 6}$ and the alkyne functionality of the ethynylglycine synthon 1a (Fig. 23) (Pulley et al. 1999, 2005).
In the key benzannulation reaction, the use of ultrasounds was found to improve yields.

The last oxidation step of arylglycinols $\mathbf{1 0 9}$ to arylglycines 110 proved to be problematic: the best results were obtained with a Dess-Martin oxidation followed by sodium chlorite oxidation using the Cbz-protecting group. The same oxidation performed on one of the Boc-protected arylglycinols proceeded in a lower yield (see, note 21 in Pulley et al. 2005).

Compounds 111 and 112 are serotoninergic chromanbased ligands with good activity (Fig. 24) (Holmberg et al. 2004, 2005). Badarau et al. synthesized compound 117, the 3-amino-7-azabenzofuran analogue of $\mathbf{1 1 1}$ and 112, starting from racemic ethynylglycine synthon 1a (Badarau et al. 2009). After ring opening, substitution of the methyl sulfonate in triazine $\mathbf{1 1 4}$ gave $\mathbf{1 1 5}$ which, through an intramolecular hetero-Diels-Alder reaction between the triazine residue and the alkyne moiety, led to compound $\mathbf{1 1 6}$. The reaction was carried out under microwave conditions using Cbz-protected alkyne 113. It is worth noting that, due to the presence of a good leaving group, the same reaction led to the formation of an oxazolidinone when performed on Bocprotected amino alcool 102 (Fig. 22) (Badarau et al. 2009).

Finally, the cyclopropene glutamate analogue $\mathbf{1 2 0}$ was synthesized by an Rh-catalyzed cyclopropanation of ethyl diazoacetate and ethynylglycine synthon 1a as a key step. Deprotection of oxazolidine $\mathbf{1 1 8}$ and oxidation of the alcohol finally furnished amino ester $\mathbf{1 2 0}$ although in low yield (Fig. 25) (Kumar et al. 2016). Ester deprotection proved to

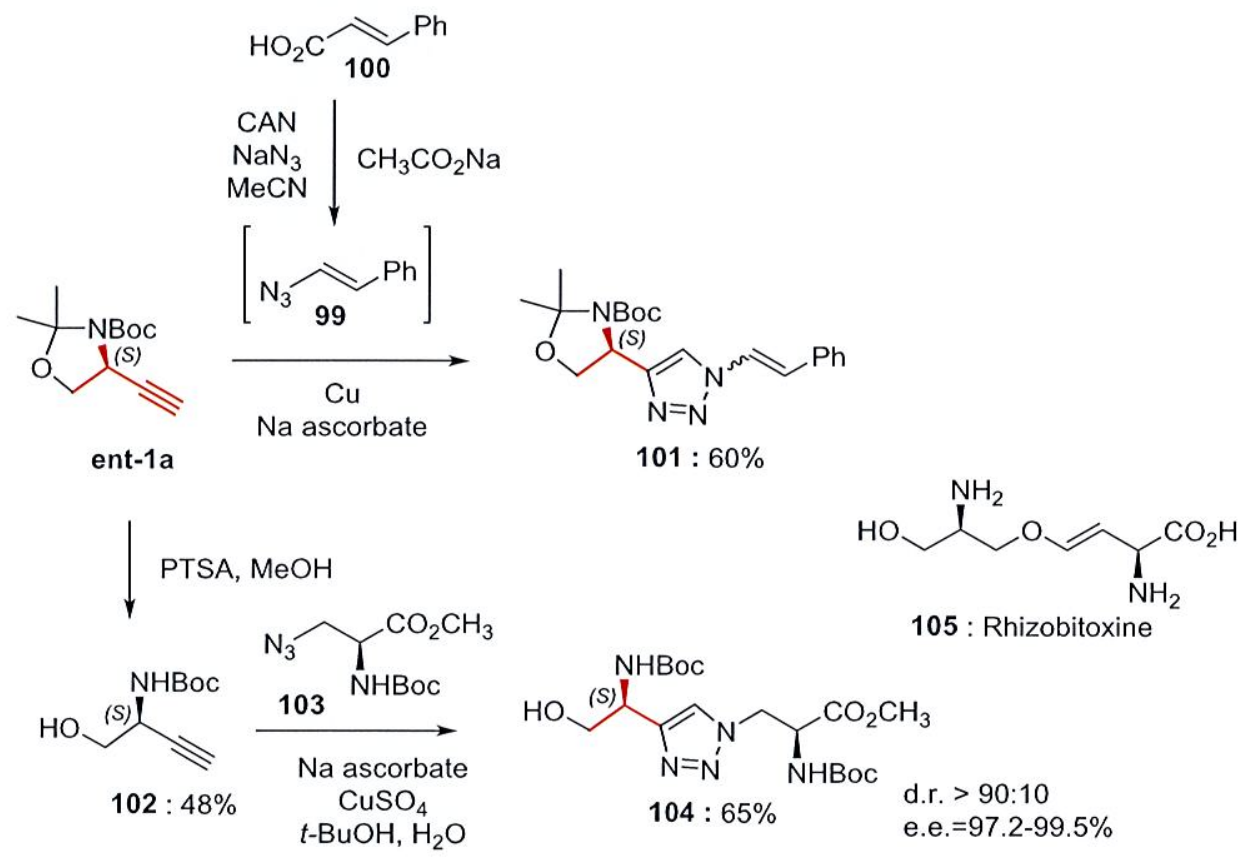

Fig. 22 Synthesis of triazole amino acid rhizobitoxine analogue $\mathbf{1 0 4}$ 


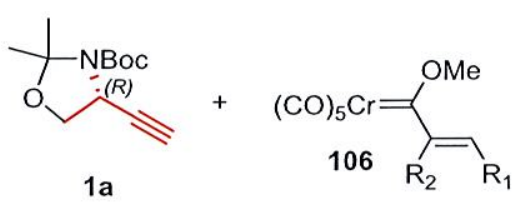<smiles>[R]c1c(OC)cc(C2=[N+]([O-])C(C)(C)OC2)c(O)c1[R]</smiles>

107 , thermal : $51-69 \%$ ultrasonic : $59-87 \%$<smiles>[R7][Y]([H])=C1C=CC=CO1</smiles><smiles>[Y]C(C)(C)O[Na]</smiles><smiles>CC(C)(C)c1ccccc1</smiles><smiles>COc1ccc(C(C)(C)C)cc1</smiles><smiles>[R2]c1c(OC)cc([14CH](CO)N[14CH3])c(OC)c1[R]</smiles>

$109: 72-75 \%$

1-TFA, $\mathrm{MeOH}$ or PTSA, THF, $\mathrm{CH}_{2} \mathrm{Cl}_{2}$

2-<smiles>CC(C)ON1C(=O)CCC1=O</smiles><smiles>[R2]c1c(OC)cc(C2=[N+]([O-])C(C)(C)OC2)c(OC)c1[R]</smiles>

$108: 73-85 \%$

$$
\begin{aligned}
& \text { 1-DMP } \\
& \text { 2- } \mathrm{NaClO}_{2}, \mathrm{NaH}_{2} \mathrm{PO}_{4}, \\
& \mathrm{MeCN} t \text {-BuOH, } \\
& \text { 2-methyl-2-butene }
\end{aligned}
$$<smiles>[R]c1c(OC)cc([C@H](NC(=O)O)C(=O)O)c(OC)c1[R]</smiles>

$110: 59-70 \%$

Fig. 23 Synthesis of arylglycine derivatives $\mathbf{1 1 0}$

be unsuccessful. The unstability of these derivatives is due to the presence of the cyclopropene moiety and the acidic $\alpha$-proton which lead to the formation of the corresponding allene (see supporting information in the reference of the work).

\section{Addition of mixed tributylstannyl cuprate to the terminal alkyne and Stille coupling reactions (Reginato et al. 1997, 2000; Crisp et al. 1997)}

Addition of stannylcuprate $\mathbf{1 2 1}$ onto ethynylglycine synthon 1a gave the vinyl copper intermediate $\mathbf{1 2 2}$. Hydrolytic workup led to the $\gamma$-stannylated (E)-ethenyloxazolidine $\mathbf{1 2 3}$ in very good yield (Reginato et al. 1997).

Stille coupling with vinyl bromide gave diene 124. The use of palladium acetate $\mathrm{Pd}(\mathrm{OAc})_{2}$ and triphenylarsine
$\mathrm{AsPh}_{3}$ as ligand proved to be necessary to obtain diene $\mathbf{1 3 0}$ when 2-bromopropene is used.

Trapping the intermediate vinyl copper 122 with electrophiles gave $\beta$-substituted stannyl allylamines $\mathbf{1 2 5}, \mathbf{1 2 6}$, and 127. Again Stille couplings led to diene 128 and triene 129 (Reginato et al. 2005a) (Fig. 26).

It is possible to obtain selectively the $\beta$-stannylated $\mathbf{1 3 1}$, the regioisomer of $123(\mathbf{1 3 1 / 1 2 3}=9: 1)$, the two compounds being separated by chromatography, using hydrostannation of ethynylglycine synthon 1a (Fig. 27) (Lin and Kazmaier 2007).

Compound 131 was subjected to Stille coupling reactions to afford alkenes $\mathbf{1 3 2}$ and $\mathbf{1 3 3}$. Vinylketones $\mathbf{1 3 2}$ were used for Michael additions, while alkenes $\mathbf{1 3 3}$ led to protected aminoalcohols $\mathbf{1 3 5}$ after oxazolidine cleavage (in two steps).

This strategy was also used in the same paper to obtain chiral amino heterocycles by hydrostannation and ring-closing metathesis (RCM) (Fig. 28) (Lin and Kazmaier 2007). 


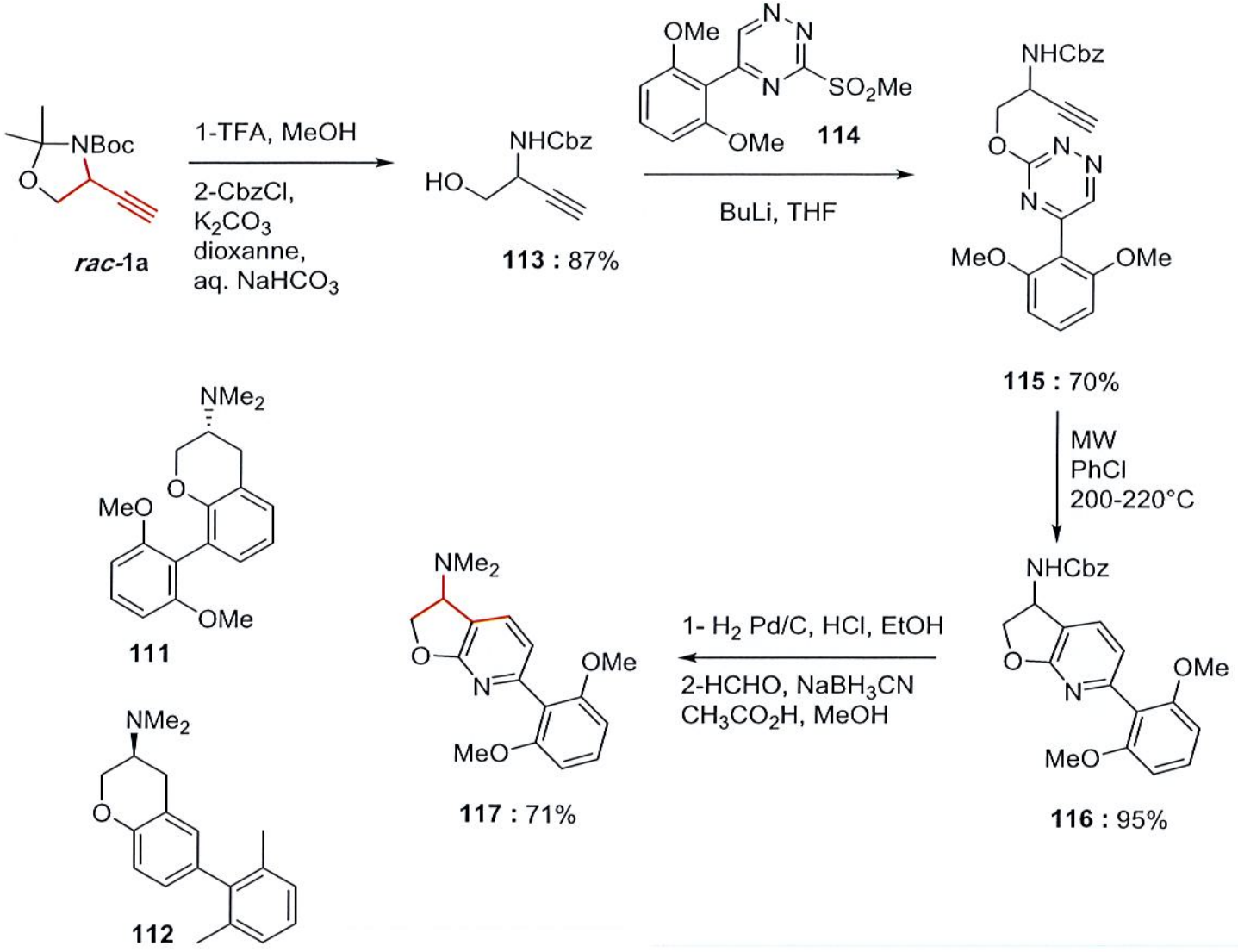

Fig. 24 Synthesis of a 3-amino-7-azabenzofuran derivative 117 analogue of serotoninergic ligands 111 and 112

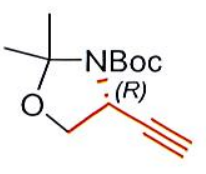

$1 a$

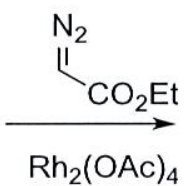

$\mathrm{Rh}_{2}(\mathrm{OAc})_{4}$

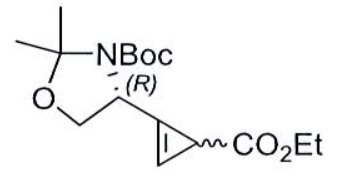

118 : $55-60 \%$

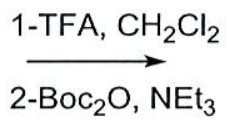<smiles>CCOC(=O)C1C2=C1C2[13C](=O)O[Na]</smiles>

119 : $99 \%$ $\mid \begin{aligned} & \mathrm{H}_{5} \mathrm{IO}_{6}, \mathrm{CrO}_{3} \text { cat } \\ & \mathrm{CH}_{3} \mathrm{CN}, \mathrm{H}_{2} \mathrm{O}\end{aligned}$<smiles>CCOC(=O)C1C=C1[C@@H](NC(C(=O)O)C(=O)O)C(=O)O</smiles>

120 : $16 \%$

Fig. 25 Synthesis of a cyclopropene amino acid glutamate analogue derivative $\mathbf{1 2 0}$

For this purpose, dienes 137 and 138 were needed. Because acidic cleavage of the oxazolidine ring could not be performed on the stannylated oxazolidine 131 (Fig. 27), alkyne ent-102 was first obtained by acidic deprotection and hydrostannation was performed to give vinyl stannane $\mathbf{1 3 6}$ which was converted to dienes 137 and $\mathbf{1 3 8 .}$

Stille coupling and ring-closing metathesis led to heterocycles 141-142 and 147-148 (Fig. 28). 


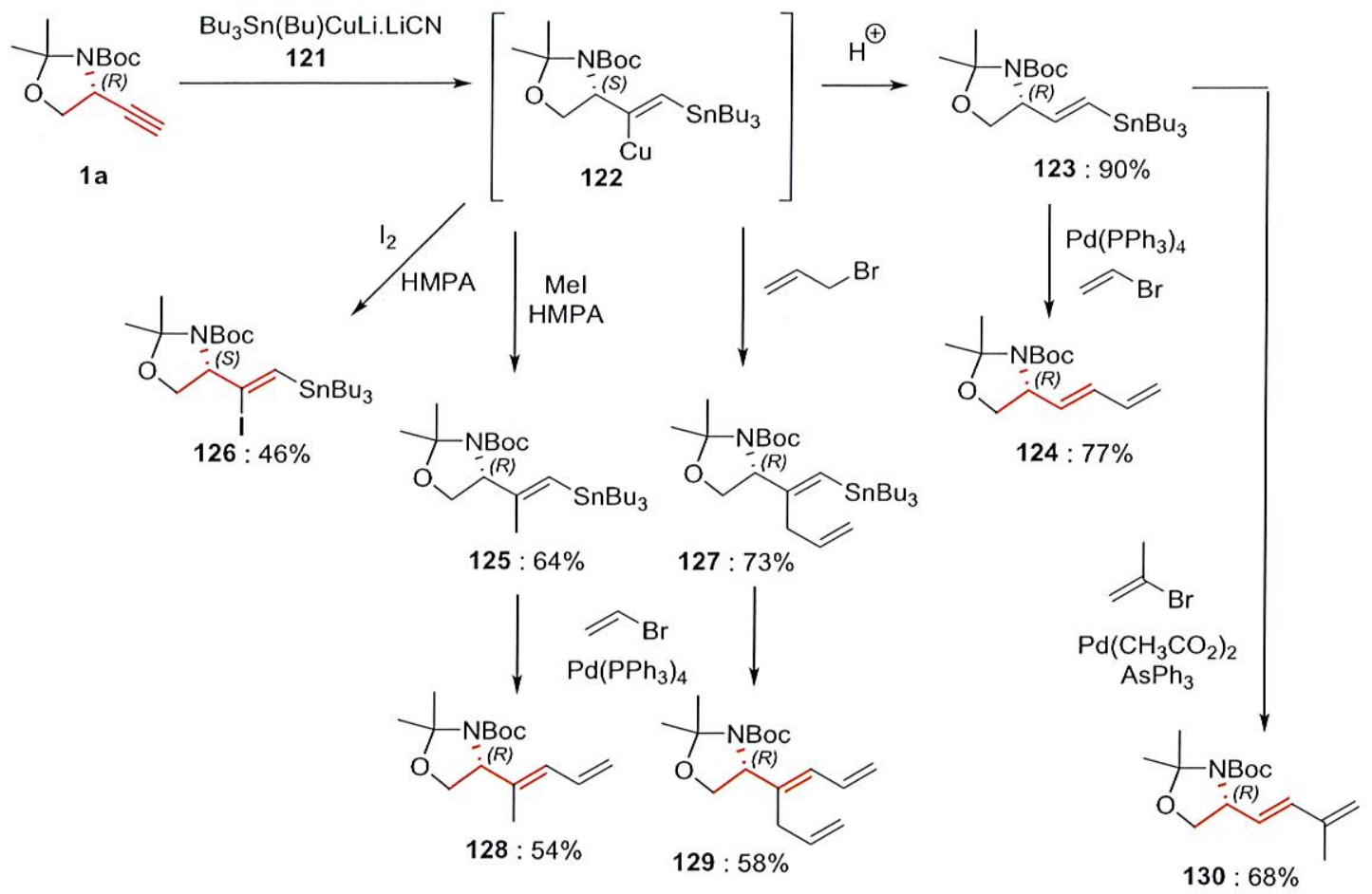

Fig. 26 Synthesis of diene and triene amino acid precursors 124, 128, 129, and 130

\section{Metal-catalyzed C-C bond-forming reaction to the terminal alkyne (other than Pd-catalyzed couplings)}

Enantiomerically pure $\mathrm{N}$-Boc-protected $(R, R)$-diaminosuberic acid 152 was synthesized using a copper-catalyzed dimerization of ethynylglycine synthon 1a as key step, followed by usual transformations (hydrogenation, deprotection, and oxidation). This strategy would allow a facile introduction of tritium or deuterium (Fig. 29) (Callahan et al. 2000).

It is possible to synthesize a $C$-glycosyl derivative using an indium-mediated alkynylation reaction between a glycal or sugar derivative and alkynyl iodides under Barbier conditions (Ayed et al. 2010a). This reaction, when applied to alkynyliodide 153 (derived from ethynylglycine synthon 1a) and carbonyl compound $\mathbf{1 5 4}$ (derived from gluconolactone), leads to propargylic alcohol $\mathbf{1 5 5}$ in $66 \%$ yield, as a mixture of diastereoisomers (Fig. 30) (Ayed et al. 2010b).

Unfortunately, when the same alkynyliodide 153 was treated with tri-O-acetyl-D-glucal $\mathbf{1 5 6}$, no coupling product was detected in the same reaction conditions. Instead of the $C$-glycosylated derivative $\mathbf{1 5 7}$, the cyclic compound 158 was formed in $91 \%$ yield because of Boc intramolecular cyclization (Fig. 30) (Ayed et al. 2010a) (see also the discussion about the amino protecting group issue in our precedent Part I report) (Benfodda et al. 2015).
Indeed, when different protecting groups in alkynyliodide 153 were used (compounds 159 and 161), the coupling products 160 and 162 (Ferrier-type rearrangement) could be formed exclusively in the $\alpha$-anomeric form (Fig. 31) (Ayed et al. 2010b, a).

Finally, propargyl hydroxylamine 164 was obtained in $75 \%$ yield by a $\mathrm{C}-\mathrm{C}$ bond-forming reaction using a Lewis acid/metal amide hybrid-catalyzed reaction of ethynylglycine synthon 1a with nitrone 163 (Fig. 32) (Yamashita et al. 2014).

\section{Miscellaneous}

Ethynylglycine synthon 1a was converted to allenic carbamate 165 using the Crabbé reaction (Fig. 33) (Crabbe et al. 1985; Alcaide et al. 2013).

The 6-methylene 1,3-oxazinan-2-one $\mathbf{1 6 6}$ has then been obtained using a gold-catalyzed oxycyclization of the allene 165 at room temperature (6-endo-dig oxyauration, kinetically controlled product). The same reaction conducted at high temperature led to a complex mixture (Fig. 33).

It is worth noting that the same reactions were performed (among other allenic carbamates) on the proline derivative 167. In that case, the thermodynamically favored 1,3-oxazine-2-one 170 was formed at high temperature (6-exo-dig oxyauration) (Fig. 34) (Alcaide et al. 2013). 

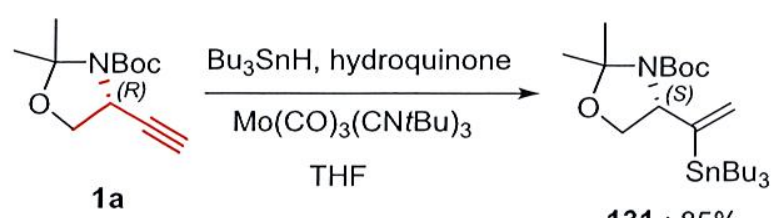

$131: 85 \%$

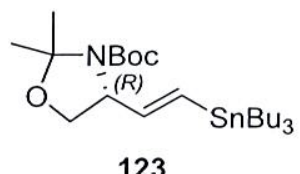

123

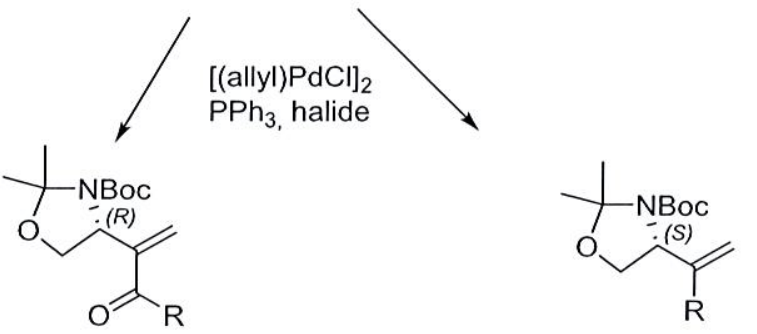

(R=Me : $68 \%$, R=Phe : $82 \%)$

$(\mathrm{R}=\mathrm{Bn}: 94 \%, \mathrm{R}=\mathrm{All}: 92 \%, \mathrm{R}=\mathrm{Ph}: 58 \%)$

132<smiles>[R]C(=O)C(CC([R])[R])C1COC(C)(C)N1[R16]#N</smiles>

(R=Me, Phe ; $\mathrm{R}_{1}=\mathrm{CO}_{2} \mathrm{Et}, \mathrm{CN}: 58-82 \%$ )

134
133

1) PTSA, $\mathrm{MeOH}, \mathrm{H}_{2} \mathrm{O}$

2) $\mathrm{NEt}_{3}, \mathrm{Boc}_{2} \mathrm{O}$<smiles>[R]C(=C)[C@H](N)CO</smiles>

( $\mathrm{R}=\mathrm{Bn}: 82 \%, \mathrm{R}=\mathrm{All}: \mathbf{7 8 \%}, \mathrm{R}=\mathrm{Ph}: \mathbf{7 5 \%})$

135

Fig. 27 Synthesis of functionalized amino alcohols and heterocycles by hydrostannation

Ethynylglycine synthon 1a was converted to protected propargylamine alcohol $\mathbf{1 7 1}$ which was subjected to intramolecular Mitsunobu reaction to lead to aziridine 172. Bromoallene 174 was then synthesized from aziridine 172 via an acid-mediated ring opening reaction and bromination through mesylate 173 (Fig. 35) (Ohno et al. 2002).

Bromoallene $\mathbf{1 7 4}$ was used as a model in the course of the study of the intramolecular amination reaction of chiral bromoallenes into 2-ethynylaziridines in basic conditions (for example $(R)$ and $(S)-172$ resulted from syn- and anti- $S_{N} 2^{\prime}$ processes when bromoallene $\mathbf{1 7 4}$ was treated with LHMDS) (Fig. 35) (Ohno et al. 2002).

To circumvent the Wittig strategy to prepare alkene $\mathbf{1 7 5}$ from Garner's aldehyde 2a (that proved to be unreliable to some authors) (Belanger et al. 2009), ethynylglycine synthon 1a was hydrogenated to alkene $\mathbf{1 7 5}$ using Lindlar catalyst. Cross-coupling metathesis using Grubbs' catalyst II led to alkene 177. This compound is an intermediate in the synthesis of cyclic peptide $\mathbf{1 7 8}$ as a complexing agent of poly(vinyl alcohol) (PVA). This chemistry is outside the scope of this review and will not be detailed here (Fig. 36) (Belanger et al. 2009).

\section{Conclusion}

This review shows the great potentiality of ethynylglycine synthon as a polyfunctional chiral building block available for the synthesis of biologically relevant compounds, from "simple" to more "complex" structures. The terminal alkyne moiety has been exploited in metallation and reaction with a large variety of electrophile; in metalcatalyzed coupling reactions (Pd: Sonogashira, $\mathrm{Cu}, \mathrm{In}$ ); in cycloaddition reactions on nitrones, nitrile oxides, azide (Huisgen reaction), Fischer chromium carbene complexes, triazines (hetero-Diels-Alder), and ethyl diazo acetate (Rh-catalyzed cyclopropenation); in additions of stannylcuprates followed by Stille coupling reactions. Most of the times, the integrity of the chirality in ethynylglycine synthon was maintained in the final compounds or used as a chiral inducer.

The well-known reactivity of the terminal alkyne together with the presence of the stable chiral aminoalcohol substructure explain the increasing use of the ethynylglycine synthon in recent years (2005-2017: 35 reports) and suggests a great future. 


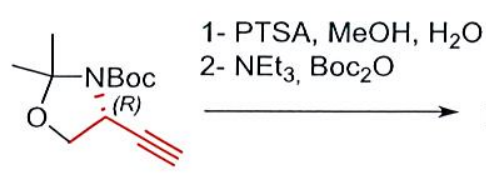

1 a

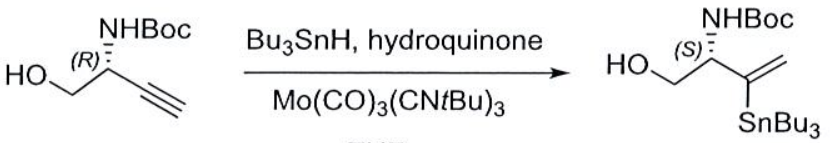

ent-102

THF

$136: 81 \%$

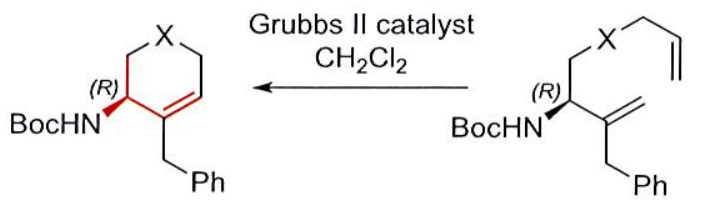

$141(\mathrm{X}=\mathrm{O}): 52 \%$

$142(X=N B o c): 78 \%$
$139(\mathrm{X}=\mathrm{O}): 89 \%$

140 (X=NBoc) : 74\%
$\mathrm{BnBr}, \mathrm{Pd}\left(\mathrm{PPh}_{3}\right)_{4}$

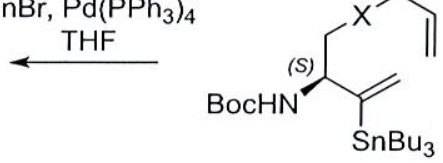

$137(X=0): 84 \%$

138 (X=NBoc) : $57 \%$

$\mathrm{CH}_{3} \mathrm{COCl}$ [(allyl)PdCl $]_{2}$

$\mathrm{PPh}_{3}$<smiles>[X]C1CC=C(C(C)OCc2ccccc2)[C@H](N=C)C1</smiles>

$147(X=0): 43 \%$

148 (X=NBoc) : $81 \%$
Grubbs II catalyst $\mathrm{CH}_{2} \mathrm{Cl}_{2}$

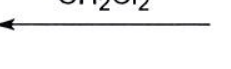

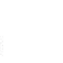

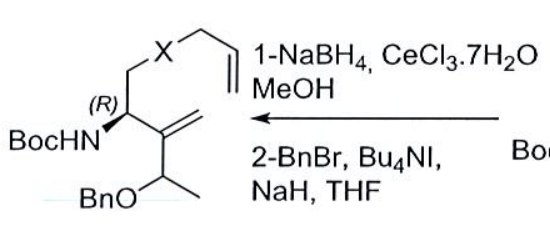

$145(X=0): 62 \%$

$146(X=N B o c): 56 \%$
$43(X=0): 76 \%$

144 (X=NBoc) : $76 \%$

Fig. 28 Synthesis of functionalized amino alcohols and heterocycles by hydrostannation

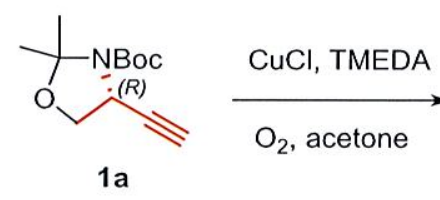

$1 \mathrm{a}$

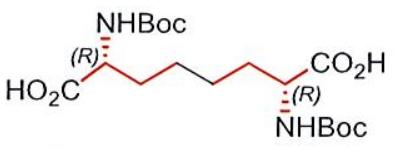

$152: 20 \%$

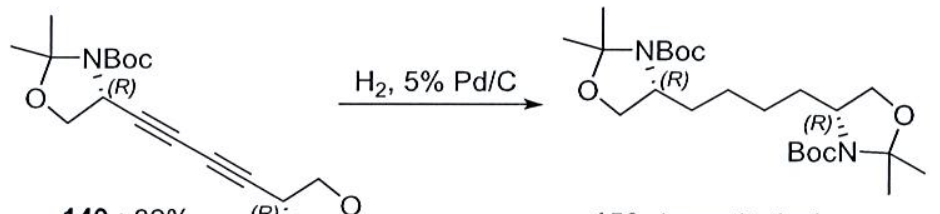

150 (quantitative)

Amberlyst resin $\mathrm{MeOH}, \mathrm{H}_{2} \mathrm{O}$

Jones reagent

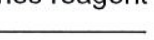

$\mathrm{HO}(\mathrm{R}$

NHBoc<smiles>CC[Te]CCCCC(C)CO</smiles>

NHBoc

Fig. 29 Synthesis of protected diaminosuberic acid $\mathbf{1 5 2}$ 

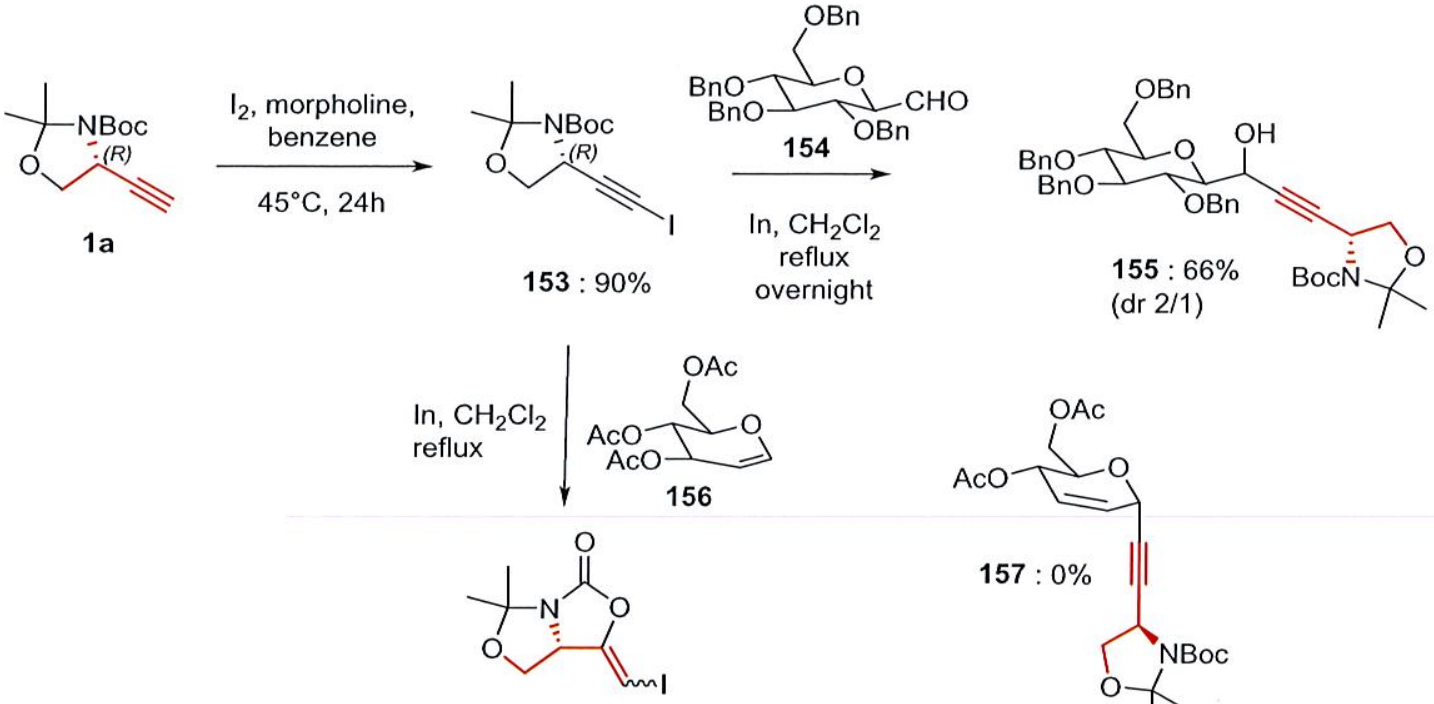

$158: 91 \%$

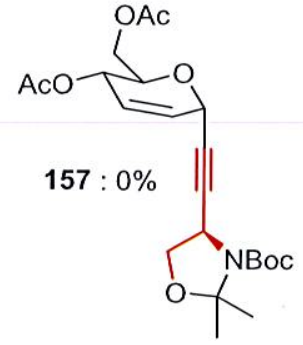

Fig. 30 Synthesis of $C$-glycosylated derivatives and the amino protecting group issue

Fig. 31 Synthesis of $C$-glycosylated derivatives and the amino protecting group issue

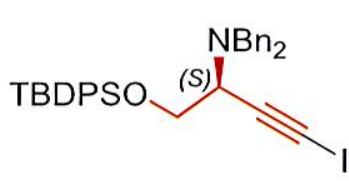

159

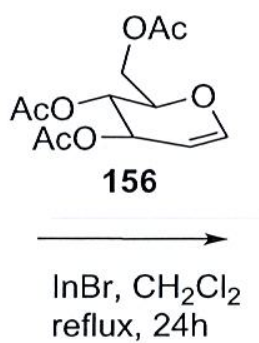

reflux, $24 \mathrm{~h}$

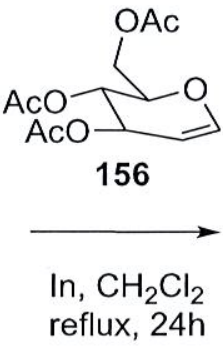<smiles>CC(C)=O</smiles>

$160: 40 \%$<smiles>CC1(C)OC[C@@H](C#CI)N1C(=O)c1ccccc1-c1ccccc1</smiles><smiles>CC(=O)COC1C=CC(C#C[R16](C)(C)C)C(COC(C)=O)C(COC(C)=O)C=C1</smiles>

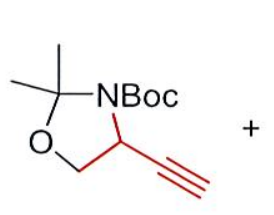

$1 \mathrm{a}$

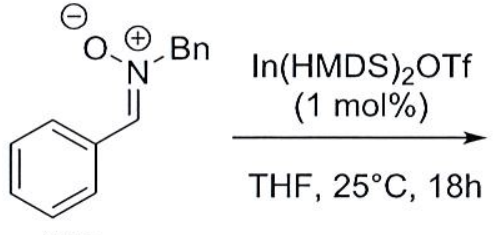

163<smiles>CC(C)(C)OC(=O)C1COC(C)(C)[N+]1(C(=O)O)C(C)(C)C</smiles>

Fig. 32 Synthesis of propargyl hydroxylamine derivative $\mathbf{1 6 4}$ 


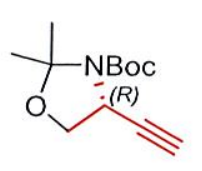

$1 \mathrm{a}$

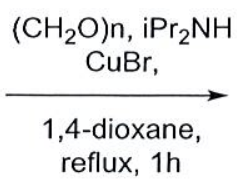

reflux, $1 \mathrm{~h}$
$\mathrm{AuClPPh}_{3}(2.5 \mathrm{~mol} \%)$

$\operatorname{AgOTf}(2,5 \mathrm{~mol} \%)$

PTSA $(10 \mathrm{~mol} \%)$

$\mathrm{CH}_{2} \mathrm{Cl}_{2}, \mathrm{rt}, 5 \mathrm{~h}$<smiles>C=C1C[C@H]2COC(C)(C)N2C(=O)O1</smiles>

$166: 52 \%$

$165: 62 \%$<smiles>[CH]=C</smiles>

$\mathrm{AuClPPh}_{3}(2.5 \mathrm{~mol} \%)$

AgOTf $(2,5 \mathrm{~mol} \%)$

PTSA (10 mol\%)

$\mathrm{CH}_{2} \mathrm{Cl}_{2}$, sealed tube, $130^{\circ} \mathrm{C}$

complex mixture

Fig. 33 Synthesis of oxazinone $\mathbf{1 6 6}$
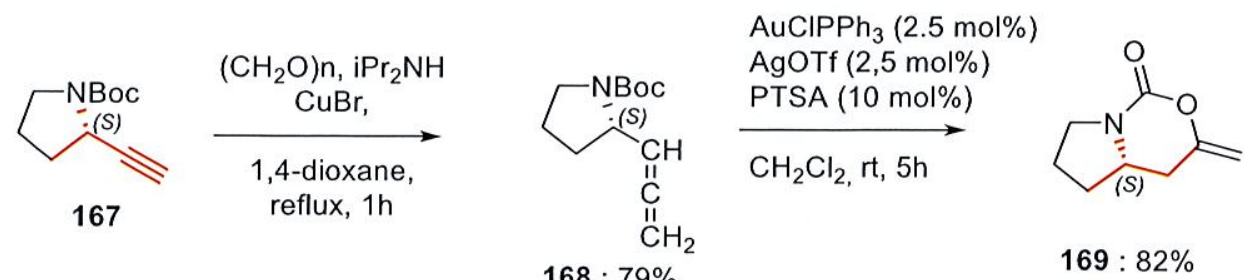

$168: 79 \%$

$$
\begin{aligned}
& \mathrm{AuCIPPh}_{3}(2.5 \mathrm{~mol} \%) \\
& \operatorname{AgOTf}(2,5 \mathrm{~mol} \%) \\
& \text { PTSA }(10 \mathrm{~mol} \%) \\
& \underset{\mathrm{CH}_{2} \mathrm{Cl}_{2}, \mathrm{rt}, 5 \mathrm{~h}}{\longrightarrow}
\end{aligned}
$$

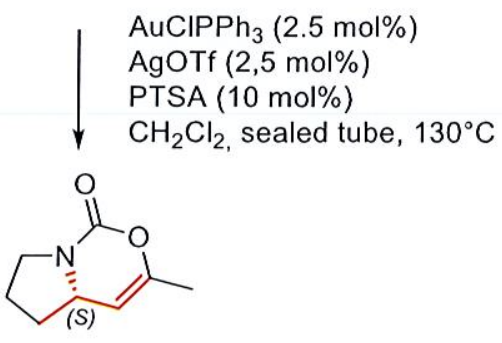

$170: 67 \%$

Fig. 34 Synthesis of oxazinones 169 and $\mathbf{1 7 0}$ 
<smiles>C#CC1COC(C)(C)N1[R6]#N</smiles>

$1 a$
1) TFA, $\mathrm{CH}_{3} \mathrm{OH}$

2) $\mathrm{MtsCl}, \mathrm{NEt}_{3}$<smiles>Cc1cc(C)c(S(=O)(=O)Cl)c(C)c1</smiles>

$\mathrm{PPh}_{3}, \mathrm{DEAD}$

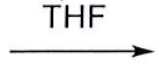

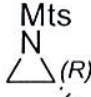

$172: 89 \%$

$\mathrm{CH}_{3} \mathrm{SO}_{3} \mathrm{H}, \mathrm{CH}_{2} \mathrm{Cl}_{2}$
$\mathrm{CuBr} .\left(\mathrm{CH}_{3}\right)_{2} \mathrm{~S}$
$\mathrm{LiBr}, \mathrm{THF}$<smiles>C#CC1([As])CN1</smiles>

(R)-172<smiles>C#CC1CN1S</smiles>

(S)-172
LHMDS

THF

$45 \%$

$(R):(S)=30: 70$

Fig. 35 Synthesis of 2-ethynyl aziridine 172, mixture of enantiomers

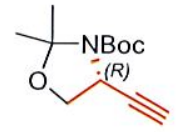

$1 \mathrm{a}$

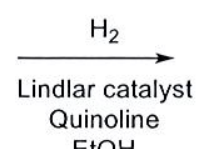

$\mathrm{EtOH}$

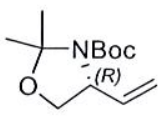

$175: 86 \%$<smiles>CS(=O)(=O)NCC=C=CBr</smiles>

$174: 74 \%$

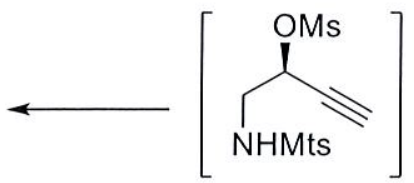

173<smiles>C=CCC(=O)OCc1ccccc1</smiles>

Fig. 36 Synthesis of cyclic peptide $\mathbf{1 7 8}$

\section{Compliance with ethical standards}

Conflict of interest The authors declare that there are no conflicts of interest.

Research subjects This review is a compilation of the previous works performed by different authors. No animal or human was used or harmed in this work.

Informed consent This manuscript is being submitted after consent was obtained from all authors, and all authors are aware of this manuscript submission.

\section{References}

Alcaide B, Almendros P, Quirós MT, Fernández I (2013) Gold-catalyzed oxycyclization of allenic carbamates: expeditious synthesis

of 1,3-oxazin-2-ones. Beilstein J Org Chem 9:818-826. https:// doi.org/10.3762/bjoc. 9.93

Ayed C, Palmier S, Lubin-Germain N et al (2010a) Indium-mediated alkynylation of sugars: synthesis of $C$-glycosyl compounds bearing a protected amino alcohol moiety. Carbohydr Res 345:25662570. https://doi.org/10.1016/j.carres.2010.07.033

Ayed C, Picard J, Lubin-Germain N et al (2010b) Synthesis of alkynes and alkynyl iodides bearing a protected amino alcohol moiety as functionalized amino acids precursors. Sci China Chem 53:19211926. https://doi.org/10.1007/s11426-010-4072-2

Badarau E, Suzenet F, Fînaru A-L, Guillaumet G (2009) Synthesis of 3-amino-8-azachromans and 3-amino-7-azabenzofurans via Inverse electron demand Diels-Alder reaction. Eur J Org Chem 2009:3619-3627. https://doi.org/10.1002/ejoc.200900191

Belanger D, Tong X, Soumare S et al (2009) Cyclic peptide-polymer complexes and their self-assembly. Chem Eur J. 15:4428-4436. https://doi.org/10.1002/chem.200802337 S4428/1-S4428/6

Benfodda Z, Bénimélis D, Reginato G, Meffre P (2015) Ethynylglycine synthon, a useful precursor for the synthesis of biologically 
active compounds: an update. Amino Acids 47:271-279. https:// doi.org/10.1007/s00726-014-1902-0

Boibessot T, Bénimèlis D, Jean M et al (2016a) Synthesis of a novel rhizobitoxine-like triazole-containing amino acid. Synlett 27:2685-2688. https://doi.org/10.1055/s-0036-1588300

Boibessot T, Bénimélis D, Meffre P, Benfodda Z (2016b) Advances in the synthesis of $\alpha$-quaternary $\alpha$-ethynyl $\alpha$-amino acids. Amino Acids 48:2081-2101. https://doi.org/10.1007/s00726-016-2276-2

Bolsakova J, Jirgensons A (2016) Synthesis of $\alpha$-Ethynyl Glycines. Eur J Org Chem 2016:4591-4602. https://doi.org/10.1002/ejoc.20160 0253

Brummond KM, Yan B (2008) Rhodium(I)-catalyzed cycloisomerization reaction of yne-allenamides: an approach to cyclic enamides. Synlett 2008:2303-2308. https://doi.org/10.1055/s-2008-1078169

Cabarrocas G, Rafel S, Ventura M, Villalgordo J (2000a) A new approach toward the stereoselective synthesis of novel quinolyl glycines: synthesis of the enantiomerically pure Quinolyl- $\beta$ amino alcohol precursors. Synlett 2000:0595-0598. https://doi. org/10.1055/s-2000-6625

Cabarrocas G, Ventura M, Maestro M et al (2000b) Reaction between hydrazines and chiral $\alpha$-acetylenic ketones: synthesis of novel enantiomerically pure pyrazolyl- $\beta$-amino alcohols $\uparrow$. Tetrahedron Asymmetry 11:2483-2493. https://doi.org/10.1016/S0957 $-4166(00) 00204-4$

Cabarrocas G, Ventura M, Maestro M et al (2001) Synthesis of novel optically pure quinolyl- $\beta$-amino alcohol derivatives from 2 -amino thiophenol and chiral $\alpha$-acetylenic ketones and their IBX-mediated oxidative cleavage to $\mathrm{N}$-Boc quinolyl carboxamides. Tetrahedron Asymmetry 12:1851-1863. https://doi. org/10.1016/S0957-4166(01)00308-1

Callahan JF, Khatana SS, Bhatnagar PK (2000) Stereoselective synthesis of diaminosuberic acid via a chiral alkynyl oxazolidine. Synth Commun 30:1213-1219. https://doi.org/10.1080/00397 910008087141

Cameron S, Khambay BPS (1998) Stereospecific synthesis of the amino acid, (S)-2-amino-(Z)-3,5-hexadienoic acid. Tetrahedron Lett 39:1987-1990. https://doi.org/10.1016/S0040 $-4039(98) 00112-9$

Chinchilla R, Nájera C (2007) The sonogashira reaction: a booming methodology in synthetic organic chemistry. Chem Rev 107:874 922. https://doi.org/10.1021/cr050992x

Chung JYL, Wasicak JT (1990) Synthesis of chiral $\alpha$-acetylenic cyclic amines from $\alpha$-amino acids: applications to differentially constrained oxotremorine analogues as muscarinic agents. Tetrahedron Lett 31:3957-3960. https://doi.org/10.1016/S0040 $-4039(00) 94471-X$

Comas-Barceló J, Harrity JPA (2017) Metal acetylides in cycloaddition reactions. Synthesis 49:1168-1181. https://doi. org/10.1055/s-0036-1588922

Crabbe P, Schlemper Elmer O, Kay Fair et al (1985) Allene Synthesis by organo-metallic reactions. Isr J Chem 26:147-151. https://doi. org/10.1002/ijch.198500085

Crisp GT, Jiang Y-L, Pullman PJ, De Savi C (1997) Elaboration of the side-chain of amino acid derivatives by palladium catalysed couplings. Tetrahedron 53:17489-17500. https://doi.org/10.1016/ S0040-4020(97)10197-1

Dondoni A, Mariotti G, Marra A, Massi A (2001) Expeditious synthesis of $\beta$-linked glycosyl serine methylene isosteres $(\beta-C$-gly ser) via ethynylation of sugar lactones. Synthesis. https://doi. org/10.1055/s-2001-18058

Erdsack J, Krause N (2007) Synthesis of furanomycin derivatives by gold-catalyzed cycloisomerization of $\alpha$-hydroxyallenes. Synthesis 2007:3741-3750. https://doi.org/10.1055/s-2007-990860
Evidente A, Kornienko A, Cimmino A et al (2014) Fungal metabolites with anticancer activity. Nat Prod Rep 31:617-627. https://doi. org/10.1039/C3NP70078J

Falorni M, Giacomelli G, Spanu E (1998) Synthesis of new $\alpha$-aminoacids containing the isoxazole moiety. Tetrahedron Lett 39:92419244. https://doi.org/10.1016/S0040-4039(98)02010-3

Frydenvang K, Pickering DS, Greenwood JR et al (2010) Biostructural and pharmacological studies of bicyclic analogues of the 3-isoxazolol glutamate receptor agonist ibotenic acid. J Med Chem 53:8354-8361. https://doi.org/10.1021/jm101218a

Giacomelli G, De Luca L, Porcheddu A (2003) A method for generating nitrile oxides from nitroalkanes: a microwave assisted route for isoxazoles. Tetrahedron 59:5437-5440. https://doi.org/10.1016/ S0040-4020(03)00859-7

Goswami K, Duttagupta I, Sinha S (2012a) Synthesis of optically active 2- and 3-indolylglycine derivatives and their oxygen analogues. J Org Chem 77:7081-7085. https://doi.org/10.1021/jo300708h

Goswami K, Paul S, Bugde ST, Sinha S (2012b) Synthesis of optically active homotryptophan and its oxygen and sulfur analogues. Tetrahedron 68:280-286. https://doi.org/10.1016/j.tet.2011.10.055

Goswami K, Chakraborty A, Sinha S (2013) Synthesis of optically active selenium-containing isotryptophan, homoiso-tryptophan, and homotryptophan. Eur J Org Chem 2013:3645-3647. https:// doi.org/10.1002/ejoc.201300352

Govek SP, Overman LE (2007) Total synthesis of (+)-asperazine. Tetrahedron 63:8499-8513. https://doi.org/10.1016/j.tet.2007.05.127

Guillarme S, Plé K, Haudrechy A (2006) Selective synthesis of $\alpha$ - $C$ (Alkynyl)-galactosides by an efficient tandem reaction. J Org Chem 71:1015-1017. https://doi.org/10.1021/jo0519817

Holmberg P, Sohn D, Leideborg R et al (2004) Novel 2-aminotetralin and 3-aminochroman derivatives as selective serotonin 5-HT7 receptor agonists and antagonists. J Med Chem 47:3927-3930. https://doi.org/10.1021/jm0498102

Holmberg P, Tedenborg L, Rosqvist S, Johansson AM (2005) Novel 3-aminochromans as potential pharmacological tools for the serotonin 5-HT7 receptor. Bioorg Med Chem Lett 15:747-750. https ://doi.org/10.1016/j.bmcl.2004.11.013

Huisgen R (1963) 1,3-Dipolar Cycloadditions. Past and Future. Angew Chem Int Ed Engl 2:565-598. https://doi.org/10.1002/anie.19630 5651

Katagiri K, Tori K, Kimura Y et al (1967) A new antibiotic. furanomycin, an isoleucine antagonist. J Med Chem 10:1149-1154. https:// doi.org/10.1021/jm00318a035

Kavitha M, Mahipal B, Mainkar PS, Chandrasekhar S (2011) Click reaction on in situ generated $\beta$-azidostyrenes from cinnamic acid using CAN-NaN3: synthesis of $N$-styryl triazoles. Tetrahedron Lett 52:1658-1662. https://doi.org/10.1016/j.tetlet.2011.01.129

Khutorianskyi A, Chalyk B, Borysko P et al (2017) Difluoromethyl nitrile oxide ( $\mathrm{CF} 2 \mathrm{HCNO})$ : a neglected chemical reagent. Eur J Org Chem 2017:3935-3940. https://doi.org/10.1002/ejoc.20170 0764

Kumar P, Shukhman D, Laughlin ST (2016) A photocaged, cyclopropene-containing analog of the amino acid neurotransmitter glutamate. Tetrahedron Lett 57:5750-5752. https://doi.org/10.1016/j. tetlet.2016.10.106

Lin H, Kazmaier U (2007) Regioselective mo-catalyzed hydrostannations as key steps in the synthesis of functionalized amino alcohols and heterocycles. Eur J Org Chem 2007:2839-2843. https:// doi.org/10.1002/ejoc.200700126

Mallampudi NA, Reddy GS, Maity S, Mohapatra DK (2017) Gold(I)Catalyzed Cyclization for the Synthesis of 8-Hydroxy-3-substituted Isocoumarins: total Synthesis of Exserolide F. Org Lett 19:2074-2077. https://doi.org/10.1021/acs.orglett.7b00673

Mazuela J, Antonsson T, Johansson MJ et al (2017) Direct Synthesis of N-Alkyl Arylglycines by Organocatalytic Asymmetric Transfer 
Hydrogenation of N-Alkyl Aryl Imino Esters. Org Lett. https:// doi.org/10.1021/acs.orglett.7b02627

Meffre P, Le Goffic F (1996) $\beta, \gamma$-Alkynyl $\alpha$-amino acids: a synthetic challenge. Amino Acids 11:313-328. https://doi.org/10.1007/ BF00807939

Meffre P, Gauzy L, Branquet E et al (1996) Synthesis of optically active $\beta, \gamma$-alkynylglycine derivatives. Tetrahedron 52:11215-11238. https://doi.org/10.1016/0040-4020(96)00630-8

Ohno H, Ando K, Hamaguchi H et al (2002) A highly cis-selective synthesis of 2-ethynylaziridines by intramolecular amination of chiral bromoallenes: improvement of stereoselectivity based on the computational investigation. J Am Chem Soc 124:15255-15266. https://doi.org/10.1021/ja0262277

Owens LD, Guggenheim S, Hilton JL (1968) Rhizobium-synthesized phytotoxin: an inhibitor of $\beta$-cystathionase in Salmonella typhimurium. Biochim Biophys Acta BBA Gen Subj 158:219-225. https://doi.org/10.1016/0304-4165(68)90134-7

Pulley SR, Sen S, Vorogushin A, Swanson E (1999) Diaryl ethers using fischer chromium carbene mediated benzannulation. Org Lett 1:1721-1723. https://doi.org/10.1021/o1990949u

Pulley SR, Czakó B, Brown GD (2005) Synthesis of arylglycines via the Dötz benzannulation reaction. Tetrahedron Lett 46:90399042. https://doi.org/10.1016/j.tetlet.2005.10.105

Raji Reddy C, Krishna G, Kavitha N et al (2012) Access to 2,3-disubstituted benzofurans through one-pot acid-catalyzed nucleophilic substitution/TBAF-mediated oxacycloisomerization. Eur J Org Chem 2012:5381-5388. https://doi.org/10.1002/ejoc.201200708

Reginato G, Mordini A, Degl'Innocenti A, Caracciolo M (1995) Stereoselective synthesis of (R)-(-)-2,2-dimethyl-3-t-butoxycarbonyl4-ethynyl-oxazolidine: a chiral building block for the synthesis of a new class of substituted alkynes. Tetrahedron Lett 36:82758278. https://doi.org/10.1016/0040-4039(95)01725-w

Reginato G, Mordini A, Caracciolo M (1997) Synthetic Elaboration of the Side Chain of (R)-2,2-dimethyl-3-(tert-butoxycarbonyl)4-ethynyloxazolidine: a new regio-and stereoselective strategy to $\delta$-functionalized $\beta$-amino alcohols. J Org Chem 62:6187-6192. https://doi.org/10.1021/jo970619s

Reginato G, Mordini A, Valacchi M (1998) A stereoselective approach to the synthesis of $\gamma$-silylated amino acids. Tetrahedron Let 39:9545-9548. https://doi.org/10.1016/S0040-4039(98)02120-0

Reginato G, Mordini A, Valacchi M, Grandini E (1999) Silylcupration of $(R)$-2,2-Dimethyl-3-(tert-butoxycarbonyl)-4-ethynyloxazolidine: a stereoselective approach to the synthesis of $\gamma$-silylated saturated and unsaturated $\alpha$-amino acids. J Org Chem 64:92119216. https://doi.org/10.1021/jo991272r

Reginato G, Mordini A, Verrucci M et al (2000) A new approach to non racemic saturated and unsaturated 5-aminoalkyl methyl ketones. Tetrahedron Asymmetry 11:3759-3768. https://doi.org/10.1016/ S0957-4166(00)00335-9

Reginato G, Gaggini F, Mordini A, Valacchi M (2005a) Stereoselective synthesis of dienylamines: from amino acids to E-alkene dipeptide isosters. Tetrahedron 61:6791-6800. https://doi.org/10.1016/j. tet.2005.04.068

Reginato G, Meffre P, Gaggini F (2005b) Ethynylglycine synthon from Garner's aldehyde: a useful precursor for the synthesis of non-natural amino acids. Amino Acids 29:81-87. https://doi.org/10.1007/ s00726-005-0184-y

Reginato G, Mordini A, Meffre P et al (2006) New unsaturated amino acids containing an allylsilane moiety on the lateral chain. Tetrahedron Asymmetry 17:922-926. https://doi.org/10.1016/j.tetas y.2006.02.017
Röhrig UF, Awad L, Grosdidier A et al (2010) Rational design of indoleamine 2,3-dioxygenase inhibitors. J Med Chem 53:11721189. https://doi.org/10.1021/jm9014718

Serrat X, Cabarrocas G, Rafel S et al (1999) A highly efficient and straightforward stereoselective synthesis of novel chiral $\alpha$-acetylenic ketones. Tetrahedron Asymmetry 10:3417-3430. https://doi.org/10.1016/S0957-4166(99)00357-2

Spangenberg T, Schoenfelder A, Breit B, Mann A (2010) 1,2-Diastereoselective $\mathrm{C}-\mathrm{C}$ bond-forming reactions for the synthesis of chiral $\beta$-branched $\alpha$-amino acids. Eur J Org Chem 2010:6005-6018. https://doi.org/10.1002/ejoc.201000865

Stecko S, Mames A, Furman B, Chmielewski M (2009) Asymmetric kinugasa reaction of cyclic nitrones and nonracemic acetylenes. J Org Chem 74:3094-3100. https://doi.org/10.1021/j0900121x

Sugawara M, Okazaki S, Nukui N et al (2006) Rhizobitoxine modulates plant-microbe interactions by ethylene inhibition. Biotechnol Adv 24:382-388. https://doi.org/10.1016/j.biotechadv.2006.01.004

Totobenazara J, Burke AJ (2015) New click-chemistry methods for 1,2,3-triazoles synthesis: recent advances and applications. Tetrahedron Lett 56:2853-2859. https://doi.org/10.1016/j.tetle t.2015.03.136

Usuki T, Yamada H, Hayashi T et al (2012) Total synthesis of COPD biomarker desmosine that crosslinks elastin. Chem Commun 48:3233-3235. https://doi.org/10.1039/C2CC17958J

von Nussbaum F, Brands M, Hinzen B et al (2006) Antibacterial Natural Products in Medicinal Chemistry-Exodus or Revival? Angew Chem Int Ed 45:5072-5129. https://doi.org/10.1002/anie.20060 0350

Wzorek JS, Knöpfel TF, Sapountzis I, Evans DA (2012) A macrocyclic approach to tetracycline natural products. investigation of transannular alkylations and michael additions. Org Lett 14:5840-5843. https://doi.org/10.1021/ol302691j

Xiong K, Fuhrmann JJ (1996) Comparison of rhizobitoxine-induced inhibition of $\beta$-cystathionase from different bradyrhizobia and soybean genotypes. Plant Soil 186:53-61. https://doi.org/10.1007/ BF00035055

Yamada H, Hayashi T, Usuki T (2015) Total synthesis of the COPD biomarker desmosine via stepwise sonogashira Cross-coupling reactions. Bull Chem Soc Jpn 88:673-683. https://doi. org/10.1246/bcsj.20140394

Yamakawa T, Ideue E, Shimokawa J, Fukuyama T (2010) Total synthesis of tryprostatins A and B. Angew Chem Int Ed 49:9262-9265. https://doi.org/10.1002/anie.201004963

Yamakawa T, Ideue E, Iwaki Y et al (2011) Total synthesis of tryprostatin A and B. Tetrahedron 67:6547-6560. https://doi.org/10.1016/j. tet.2011.05.112

Yamakawa T, Ideue E, Shimokawa J, Fukuyama T (2014) Corrigendum: total synthesis of tryprostatins A and B. Angew Chem Int Ed 53:8808-8808. https://doi.org/10.1002/anie.201401055

Yamashita Y, Saito Y, Imaizumi T, Kobayashi S (2014) A Lewis acid/ metal amide hybrid as an efficient catalyst for carbon-carbon bond formation. Chem Sci 5:3958-3962. https://doi.org/10.1039/ $\mathrm{C} 4 \mathrm{SC} 01332 \mathrm{H}$

Yanada R, Obika S, Kobayashi Y et al (2005) Stereoselective synthesis of 3-alkylideneoxindoles using tandem indium-mediated carbometallation and palladium-catalyzed cross-coupling reactions. Adv Synth Catal 347:1632-1642. https://doi.org/10.1002/ adsc. 200505147

Yasuta T, Satoh S, Minamisawa K (1999) New assay for rhizobitoxine based on inhibition of 1-aminocyclopropane-1-carboxylate synthase. Appl Environ Microbiol 65:849-852 